\title{
Neurological characterization of mice deficient in GSK3a highlight pleiotropic physiological functions in cognition and pathological activity as Tau kinase
}

\author{
Hervé Maurin ${ }^{1 \dagger}$, Benoit Lechat ${ }^{1 \dagger}$, Ilse Dewachter ${ }^{1 \dagger}$, Laurence Ris ${ }^{2}$, Justin V Louis ${ }^{1}$, Peter Borghgraef ${ }^{1}$, \\ Herman Devijver ${ }^{1}$, Tomasz Jaworski ${ }^{3}$ and Fred Van Leuven ${ }^{1 *}$
}

\begin{abstract}
Background: GSK3 3 is involved in a wide range of physiological functions, and is presumed to act in the pathogenesis of neurological diseases, from bipolar disorder to Alzheimer's disease (AD). In contrast, the GSK3a isozyme remained largely ignored with respect to both aspects.

Results: We generated and characterized two mouse strains with neuron-specific or with total GSK3a deficiency. Behavioral and electrophysiological analysis demonstrated the physiological importance of neuronal GSK3a, with GSK3 $\beta$ not compensating for impaired cognition and reduced LTP. Interestingly, the passive inhibitory avoidance task proved to modulate the phosphorylation status of both GSK3 isozymes in wild-type mice, further implying both to function in cognition. Moreover, GSK3a contributed to the neuronal architecture of the hippocampal CA1 sub-region that is most vulnerable in AD. Consequently, practically all parameters and characteristics indicated that both GSK3 isoforms were regulated independently, but that they acted on the same physiological functions in learning and memory, in mobility and in behavior.
\end{abstract}

Conclusions: GSK3a proved to be regulated independently from GSK3 $\beta$, and to exert non-redundant physiological neurological functions in general behavior and in cognition. Moreover, GSK3a contributes to the pathological phosphorylation of protein Tau.

Keywords: GSK3a knock-out, Cognition, LTP, Protein Tau, Hippocampus, Motor behavior

\section{Background}

Glycogen synthase kinase-3 (GSK3) comprises two structurally and functionally related serine-threonine kinases, active in many physiological processes [1-5]. Both are inherently active and controlled by phosphorylation at two levels: (i) inhibitory phosphorylation of serine residues S21/S9 in GSK3 $\alpha / \beta$ and (ii) tyrosine phosphorylation at Y279/Y216 in GSK3 $\alpha / \beta$, which augments their activity and relieves substrate-priming by other kinases $[6,7]$. Tyrosine phosphorylation appears an intramolecular autocatalytic event during synthesis and folding,

\footnotetext{
* Correspondence: fred.vanleuven@med.kuleuven.be

${ }^{\dagger}$ Equal contributors

'Experimental Genetics Group - LEGTEGG, Department Human Genetics, KULeuven, B-3000, Leuven, Belgium

Full list of author information is available at the end of the article
}

which makes GSK3 dual-specificity kinases. Consequently, each isozyme exists in four different phosphorylated isoforms, a molecular complexity that yet escapes analysis [5]. Combined with expression of both isozymes in most cells, and the wide diversity of substrates and molecular partners, complicates the estimation of activity and definition of functions in vivo.

Neurobiological focus on GSK3 $\beta$ stems from its demonstrated functions in neuronal differentiation and in cognition, and from its role as "tau-kinase I" in Alzheimer's disease (AD) [8]. GSK3 $\beta$ was proposed as a therapeutic target based on the treatment of bipolar disorder with lithium salts, but this however seriously suffers from limited effectiveness, narrow therapeutic window and side-effects. Moreover, the mode of action of lithium ions is not

\section{Biomed Central}


understood, because they are neither very effective nor specific inhibitors of GSK $3 \alpha / \beta[9,10]$. Experimental evidence, and localization in dendritic spines [11] supports a post-synaptic role for GSK3 $\beta$ in LTP, and by extension in synaptic plasticity [5,12-17]. Pre-synaptically, GSK3 controls activity-dependent bulk endocytosis $[18,19]$.

The structural similar kinase domains predict that GSK3 isozymes share physiological functions. Nevertheless, GSK3 $\beta$ deficient mice die in utero [20] in contrast with viability of GSK3 $\alpha$ deficient mice [21]. This extreme difference in outcome demonstrates their non-redundant physiological functions, which still need to be detailed in vivo.

Neurobiological analysis of GSK3 $\alpha$, particularly in AD remains fragmented and debated [22-25]. The contribution of GSK3 $\beta$ to phosphorylation of protein Tau is evident [26-29] while that of GSK3 $\alpha$ is hardly investigated.

In these perspectives, we studied GSK3 $\alpha$ in brain in vivo, in two newly generated mouse strains deficient in GSK3 $\alpha$, either completely in all organs or neuronspecific. This effort allowed us to investigate physiological functions and pathological roles, whereby we concentrated on the neurobiological aspects to highlight the physiological functions of GSK $3 \alpha$ in learning and memory, in mobility and behavior. In line with their independent regulation and non-redundancy, both GSK3 $\alpha$ and GSK $3 \beta$ contributed to the physiological and to the pathological phosphorylation of protein Tau.

\section{Results}

\section{Generation of two mouse strains with either neuron- specific or with total deficiency of GSK3a}

To define the physiological functions of GSK3 $\alpha$ in adult brain in vivo, we aimed in first instance to generate mice with a conditional, post-natal and neuron-specific deficiency of GSK3 $\alpha$ by the Cre-Lox system. We thereby anticipated to circumvent peripheral problems caused by GSK3 $\alpha$ deficiency in peripheral systems. Mice with floxed GSK3 $\alpha$ genes [30] were mated with transgenic mice that express Cre-recombinase under control of the mouse Thy 1 gene promoter, which we validated previously for postnatal neuronal inactivation of the Presenilin-1 gene [31].

Offspring was genotyped by classic PCR and by qPCR on DNA extracted from tail-tip biopsies, to define the presence of three possible versions of the mouse GSK3 $\alpha$ gene: wild-type, floxed or recombined (Figure 1A). Their occurrence depended on the presence of the Crerecombinase transgene, established by specific PCR (Figure 1A) [31]. The resulting GSK3 $\alpha$-deficient mice were denoted AAC to indicate the presence of the two floxed recombined GSK3 $\alpha$ alleles and of the Crerecombinase transgene necessary to disrupt the floxed GSK $3 \alpha$ genes in neurons. The matching control mice, used throughout the current studies, were denoted AA- because they were homozygous for the floxed GSK3 $\alpha$ alleles, but lacked the Cre-recombinase transgene (Figure 1A).

Serendipitously, during the expansion of the AAC colony, we encountered a male pup with a genotype indicative of a homozygous total knock-out of GSK3 $\alpha$ : only recombined GSK3 $\alpha$ alleles were detected by PCR but not the Cre-recombinase transgene. Offspring of this male founder, sired with female wild-type FvB mice, yielded littermates containing various admixtures of recombined and wild-type GSK3 $\alpha$ alleles, as expected for normal Mendelian transmission. Continued breeding yielded offspring that consistently carried only the recombined GSK3 $\alpha$ alleles without the Cre-recombinase, confirming that we had produced a mouse strain that lacked active GSK3 $\alpha$ genes completely (Figure 1A). We hereby confirmed independently, the viability of mice with total GSK3 $\alpha$ deficiency [21]. We denote the totally deficient mice as GSK3 $\alpha . K O$, to differentiate them from the neuron-specific GSK3 $\alpha$ deficient AAC mice, described above.

The biological cause of the observed total knock-out, is attributed to the incorporation of mRNA coding for the Cre-recombinase into oocytes, but without the actual genomic transgene itself being present. Subsequent fertilization by AA- sperm can result in germ-line recombination of both maternal and paternal floxed GSK $3 \alpha$ alleles, early in the developing fetus. Germ-line transmission of the recombined GSK3 $\alpha$ alleles by normal Mendelian inheritance is then no longer dependent of the presence of the Thy1-Cre-recombinase transgene. A similar situation was encountered in the study of the Presenilin gene, although the outcome then was embryonal lethality [31].

Biochemical analysis by western blotting confirmed the strongly decreased levels of GSK3 $\alpha$ in brain extracts of AAC mice, relative to the normal levels in the AA- control mice (Figure 1B). In the brain of AAC mice various types of non-neuronal cells maintain GSK3 $\alpha$ expression, e.g. glia, endothelial cells and pericytes, because they do not express the Cre-recombinase controlled by the modified mouse Thy1-gene promoter [31]. Consequently, some GSK $3 \alpha$ protein was still biochemically detectable in protein extracts of brain of AAC mice, as opposed to the complete absence of GSK3 $\alpha$ protein in brain extracts of GSK3 $\alpha . K O$ mice (Figure 1B). Western blotting further confirmed GSK3 $\alpha$ protein deficiency in lungs (Figure 1B) and in other organs of GSK3 $\alpha . K O$ mice.

Immunohistochemistry (IHC) for GSK3 $\alpha$ established the strongly decreased reaction in brain sections of AAC mice, and the annihilated staining in GSK3 $\alpha$.KO mice (Figure $1 \mathrm{C}$ ). Certain types of neurons and their processes maintained weak expression of GSK3 $\alpha$ in the AAC mice 


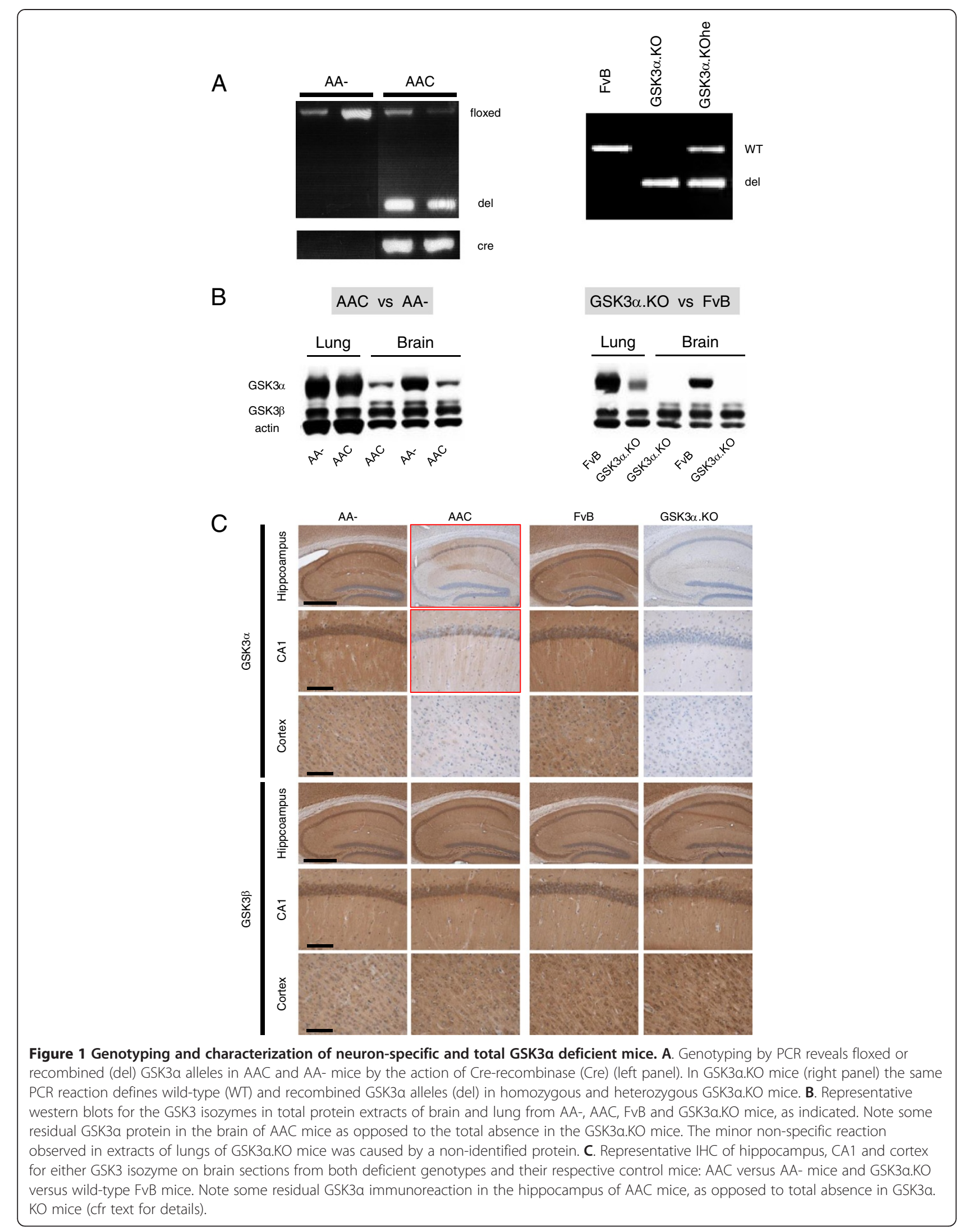


(Figure 1C; two panels with red borders). Processes and synapses in the stratum lacunosum moleculare (SLM) of AAC mice also retained GSK3 $\alpha$ immunoreactivity, although considerably less than in control AA- and wild-type FvB mice (Figure 1C). Of note, the SLM contains synapses of myelinated axons, bundled in the temporoammonic pathway that originates in the entorhinal cortex and projects onto dendrites of CA1 pyramidal neurons. These strata in the CA1 region remain to be explored in detail, because they are proposed to be affected early in AD by "dendritic amputation" [32]. Moreover, the potential contribution of the temporoammonic and perforant pathways to the spreading of pathology in the brain of AD patients is currently subject of considerable interest and debate $[33,34]$.

\section{GSK3a deficiency did not reflect on GSK3 $\beta$ levels}

The IHC images and the biochemical data described in the previous section, demonstrated the restricted and complete absence of the GSK3 $\alpha$ protein in the newly generated AAC and GSK3 $\alpha . K O$ mouse strains, respectively. The biochemical analysis for both GSK3 isoforms furthermore revealed that the GSK3 $\beta$ isozyme was hardly affected by neuronal or by total lack of GSK $3 \alpha$ (Figure 1B, Figure 2). We previously concluded for the inverse situation, i.e. in mice with neuron-specific deficiency of GSK3 $\beta$ that expression of GSK3 $\alpha$ was hardly affected [23].

That conclusion was now biochemically detailed by analyzing the repercussions of GSK3 $\alpha$ deficiency, either neuronal or total, on brain GSK3 $\beta$. Total protein levels of GSK3 $\beta$ were essentially not affected in the forebrain, nor in the hippocampus or cortex when analyzed separately (Figure 1B, Figure 2A, B). Moreover, the functionally important phosphorylation of GSK3 $\beta$ at pS9 and pY216, were essentially also not affected in the brain of $\mathrm{AAC}$ and GSK $3 \alpha . \mathrm{KO}$ mice, compared to the respective control mice (Figure 2A, B).

The combined observations demonstrated that GSK $3 \alpha$ and GSK3 $\beta$ did not effectively compensate for each other in three independent mouse strains. This outcome was in line with the fact that mice lacking GSK3 $\beta$ died around mid-term, obviously not rescued by the remaining normal GSK3 $\alpha$ levels [20]. In contrast to the total GSK3 $\beta$ deficiency, the complete lack of GSK3 $\alpha$ in mice did not significantly alter their viability at birth, nor their development into adulthood [21], confirmed here independently.

\section{General phenotypic characteristics of GSK3a-deficient mice}

This section presents selected characteristics of both strains of GSK3 $\alpha$-deficient mice to highlight similarities but also marked differences between neuron-specific and total GSK3 $\alpha$ deficient mice. Our main interest in neuronal functions led us to analyze in first instance the AAC mice with neuron-specific post-natal deficiency of GSK $3 \alpha$, and compared specified aspects with the neuron-specific GSK3 $\beta$-deficient mice that we generated recently [23]. In addition, to save valuable time and resources, we took advantage of the GSK $3 \alpha . K O$ mice and crossed them with our Tau.P301L mice, to define if GSK $3 \alpha$ acted as Tau-kinase in vivo (cfr rationale and data in subsequent sections).

The absence of neuronal GSK $3 \alpha$ did not reduce the life-expectancy of AAC mice compared to AA- mice (Figure 3A). Although the observed number of GSK3 $\alpha$. KO mice that died spontaneously is low, their lifespan appeared somewhat shorter than that of wild-type mice. Conversely, bigenic GSK3 $\alpha$. KOxTau.P301L mice (detailed below) did not survive longer than the parental Tau.P301L mice, notwithstanding an initial delay in precocious mortality (Figure 3B, arched area) [29,35]. Terminal Tau. P301L mice present with a rapid progression (2-3 weeks) of motor defects and loss in body-weight, upper-airway dysfunction with asphyxia and exhaustion, terminating in precocious death between age 8 and 11 months (mean 9.5 mo) [29,35-37]. The current data imply that GSK3 $\alpha$ did not affect this terminal phase, but contributed negatively to the early phenotype of Tau. P301L mice, characterized by defective cognition and beginning motor problems $[29,35,36]$.

The average body-weight of AAC and AA- mice was comparable (Figure 4A), while GSK3 $\alpha$.KO mice were on average heavier than age- and gender-matched wild-type mice (Figure 4B). We thereby confirmed and extended data of a similar strain of mice with total GSK3 $\alpha$ deficiency, generated and characterized independently [21]. Conversely, neuron-specific GSK3 $\alpha$ deficiency did not reflect on body-weight, implicating that GSK3 $\alpha$ affected body-weight not by central actions, but by mechanisms operating in peripheral organs and systems.

The neuron-specific deficiency of GSK3 $\alpha$ did not modify the gross neuro-anatomical features of AAC mice (Figure 1C, Figure 4A), consistent with the similar wet weight of total brain and of hippocampus, both at young (3-4 months) and advanced age (9 months) (Figure 4A). In contrast, the hippocampus and cortex were significantly heavier in adult female GSK3 $\alpha$.KO mice than in wild-type FvB females (Student's t-test, $\mathrm{p}=0.0004$ and $\mathrm{p}=0.0181$ respectively, Figure $4 \mathrm{~B})$. Adult male GSK3 $\alpha . \mathrm{KO}$ mice presented with a significant heavier brain (Student's t-test, $p=0.0212$, Figure $4 B$ ), in line with their overall more sturdy anatomy, including a larger heart and testis than wild-type males (Figure 4B, Figure 5). Our data confirmed that the size of brain and peripheral organs were differently affected by the absence of GSK3 $\alpha[21]$. 

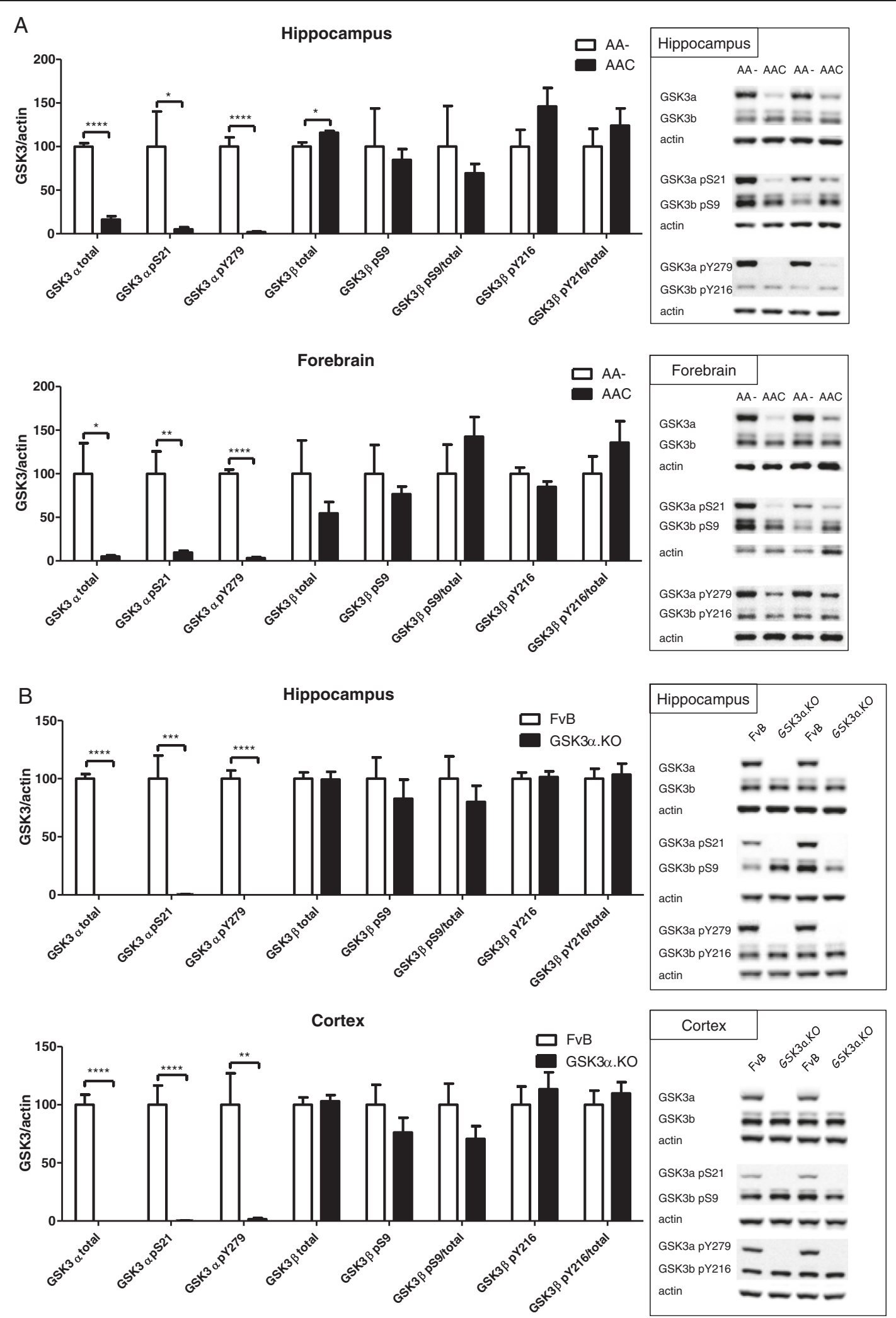

Figure $\mathbf{2}$ (See legend on next page.) 
(See figure on previous page.)

Figure 2 Biochemical analysis of GSK3 isozymes in mouse brain extracts. Levels of total GSK3 protein, pS21/S9 and pY279/Y216 in total protein extracts from hippocampus and forebrain from AAC mice compared to control AA- mice (A) and from hippocampus and cortex from GSK3a.KO mice versus wild-type FvB mice (B). Western blots were digitally quantified, normalized for actin and reported relative to the respective control mice. Data (mean \pm SEM) are statistically analyzed by unpaired Student's t-test (two-tailed), $n=6$ or 7 per genotype; ${ }^{*} p<0.05$, ${ }^{* *} p<0.01$, *** $p<0.001,{ }^{* * * *} p<0.0001$.

Surprisingly, homozygous GSK3 $\alpha . K O$ male mice proved to be infertile, in contrast to wild-type FvB mice that only very rarely produced a sterile male: we observed one individual in this study (represented by red symbol in Figure 5A). The AAC male mice sired offspring normally, with the number of litters and the number of pups per litter very similar to the control AA- males (Figure 5A). While the testes of male GSK3 $\alpha . K O$ mice were significantly larger than those of wild-type male mice, they produced similar, or somewhat lesser numbers of sperm cells (Figure 5B). Conversely, the motility of spermatozoids collected from the cauda epididymis of homozygous GSK3 $\alpha . K O$ male mice, assessed by the swim-up test, was significantly defective $(31.1 \%$ vs $110.8 \%$ in male wild-type mice; Student's t-test, $\mathrm{p}=0.032$ ) (Figure 5B). Moreover, spermatozoids produced by homozygous GSK3 $\alpha$.KO males were morphologically abnormal, presenting with kinky flagellae, while sperm heads appeared morphologically normal (Figure 5C). We concluded that the total deficiency of GSK3 $\alpha$ profoundly disturbed the morphology and the motility of sperm, causing infertility of GSK3 $\alpha$-deficient males, in contrast to normal fertility of neuron-specific GSK3 $\alpha$ deficient male mice.
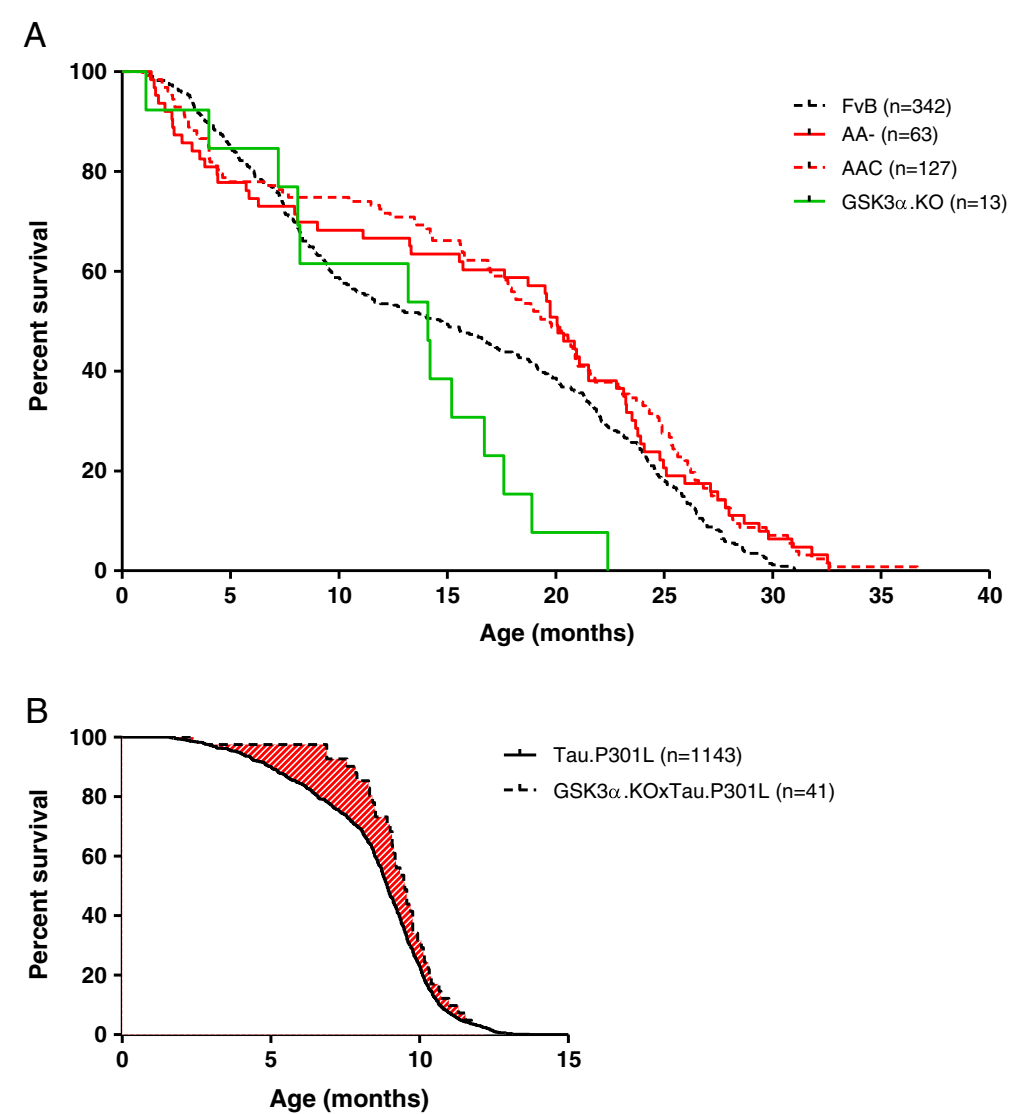

Figure 3 Kaplan-Meier survival curves. Spontaneous death of AAC, AA-, GSK3a.KO and wild-type FvB mice (panel A) and in GSK3a.KOxTau. P301L bigenic mice versus the parental Tau.P301L mice (panel B) housed in the same conditions in our breeding colony. The number of mice of either gender is indicated. Note that earlier death of GSK3a.KO mice (panel $\mathbf{A}$ ) is based on the relatively low number of mice that died spontaneously over the period of observation. The shaded area in panel B emphasizes the delayed mortality of young GSK3a.KOxTau.P301L mice, relative to the parental Tau.P301L mice. 


\section{A AAC}

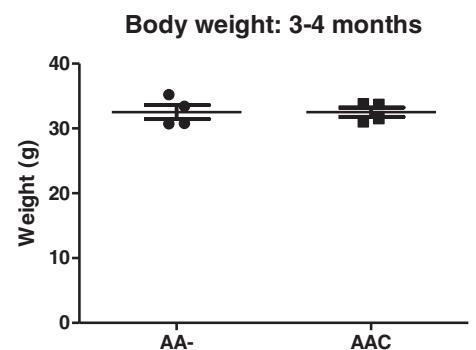

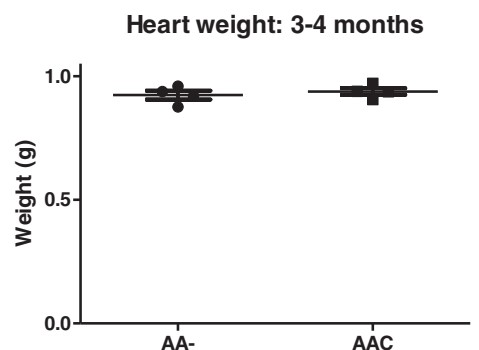
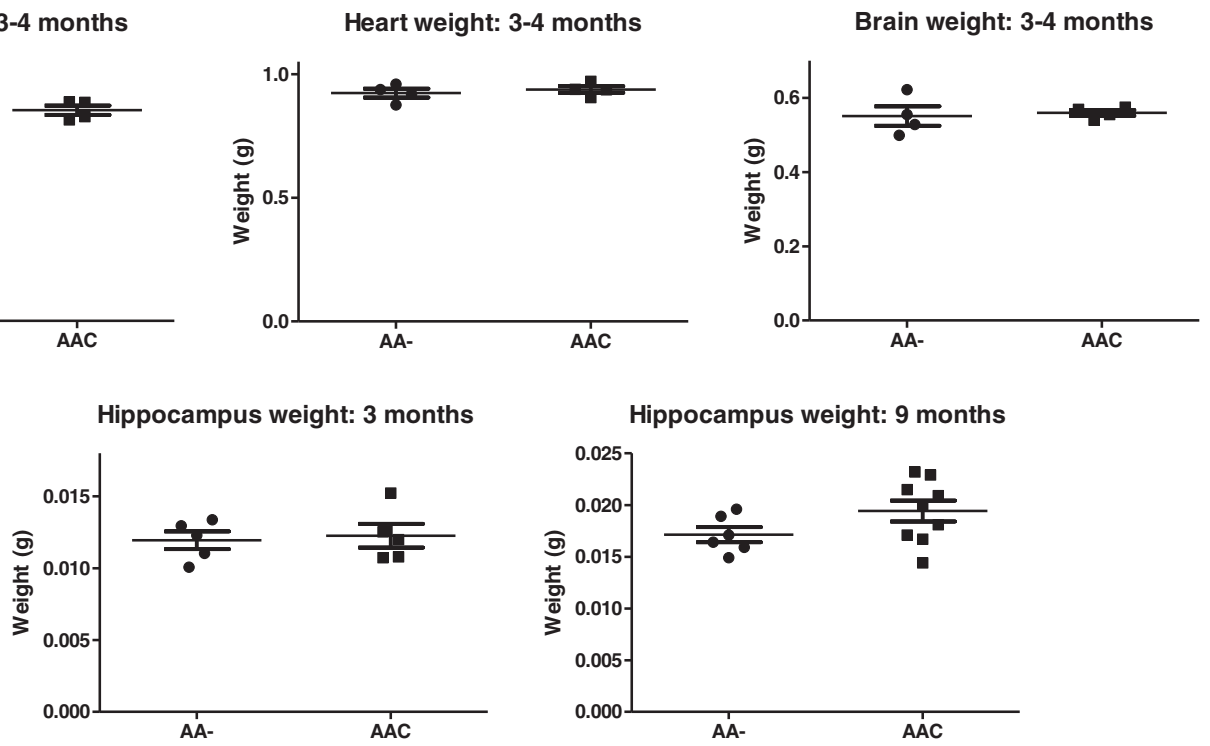

\section{B GSK3 $\alpha . K O$}

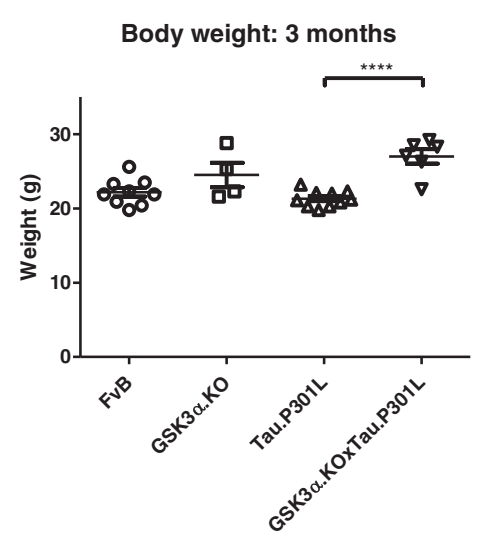

Heart weight: 8 months

Brain weight: 8 months
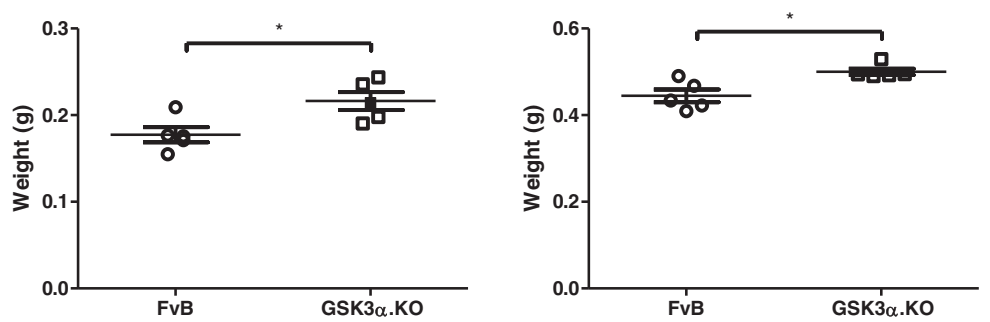

Cortex weight: 3 months

Hippocampus weight: 3 months
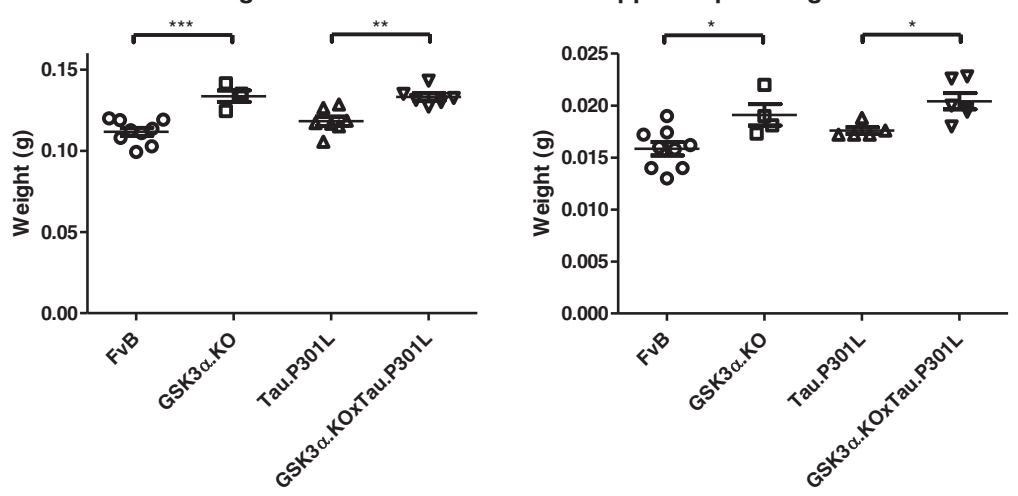

Figure 4 Body weight and brain weight. Body weight, wet weight of heart, brain, hippocampus of (A) AAC and AA- mice of either gender at young $(n=4 / 5)$ and older age $(n=6 / 9)$ and (B) of GSK3a.KO, GSK3a.KOxTau.P301L, Tau.P301L and FvB mice $(n=4 / 10)$ at young and older age. Data (mean \pm SEM) are statistically analyzed by unpaired Student's t-test (two-tailed), ${ }^{*} p<0.01,{ }^{* *} p<0.05,{ }^{* * *} p<0.001,{ }^{* * * *} p<0.0001$. 


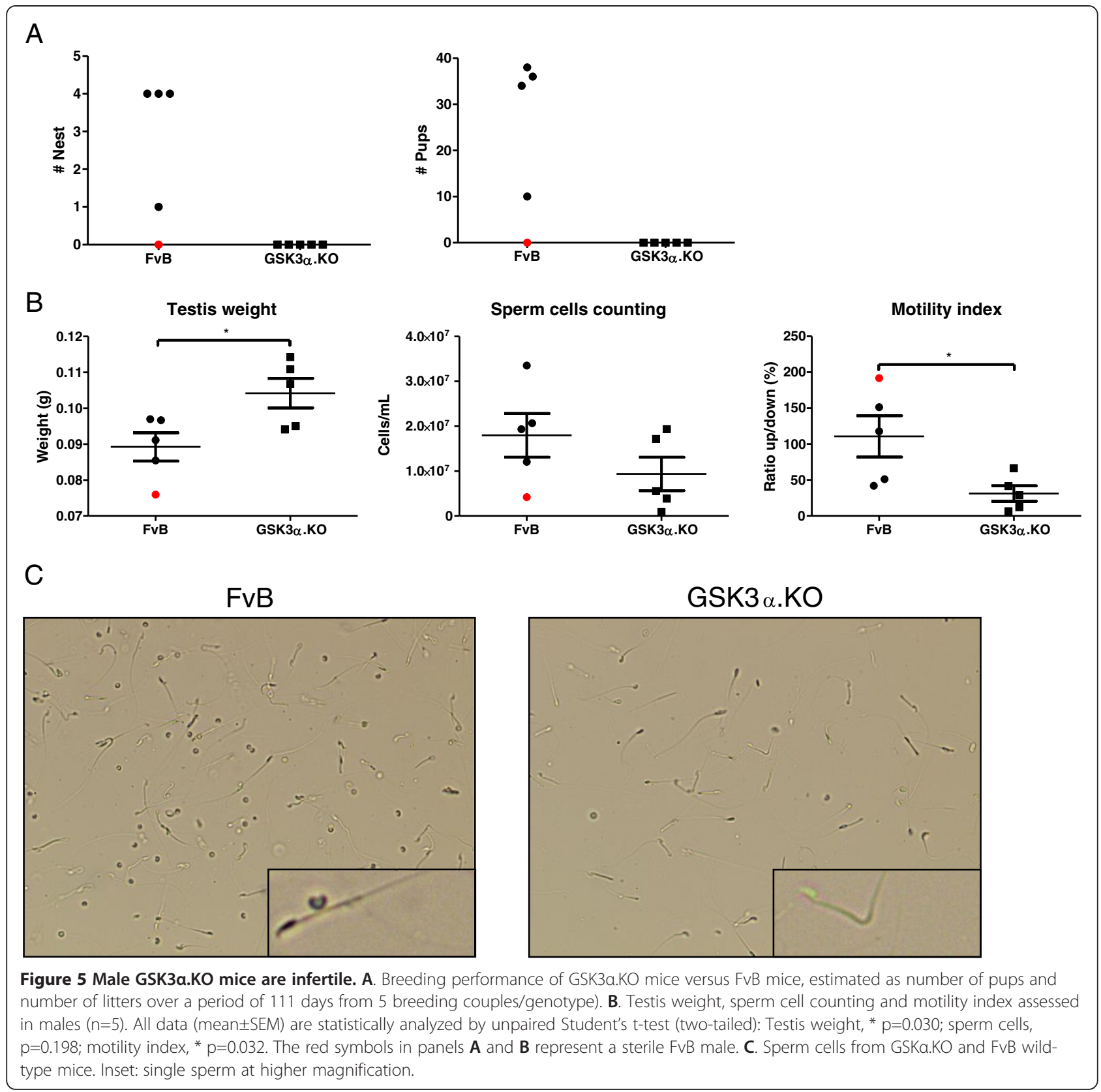

\section{Neurological characteristics of mice with neuron-specific} GSK3a deficiency

\section{Morphology of CA1}

The CA1 pyramidal brain layer in AAC mice was shorter and thinner than in control AA- mice (Figure 6A), whereas the overall wet weight of the hippocampus did not differ (Figure 4A). The surface of the CA1 pyramidal blade relative to the total CA1 area, was significantly reduced in AAC mice compared to AA- mice (respectively $6.81 \%$ vs. $9.09 \% \mathrm{p}<0.001$ ) (Figure $6 \mathrm{~A}$ ). The significant reduction of the CA1 pyramidal blade relative to the total CA1 area was also evident in GSK3 $\alpha$.KO mice compared to wild-type mice $(8.20 \%$ vs $10.35 \%$ p<0.001) (Figure 6B) despite the increased hippocampal wet weight (Figure 4B). Both sets of data consolidated the conclusion that besides GSK3 $\beta$, also GSK $3 \alpha$ contributes to the neuronal architecture of the hippocampus, and interestingly, to the CA1 sub-region that is most vulnerable in AD.

\section{Electrophysiology \& LTP}

The repercussions of lacking GSK3 $\alpha$ activity at the synaptic level was assessed electrophysiologically in acute hippocampal sections from AA- and AAC mice. We measured classic LTP as well as pre- and post-synaptic parameters in CA1 stratum radiatum (SR) [14]. The recorded inputoutput characteristic was significantly higher in AAC 


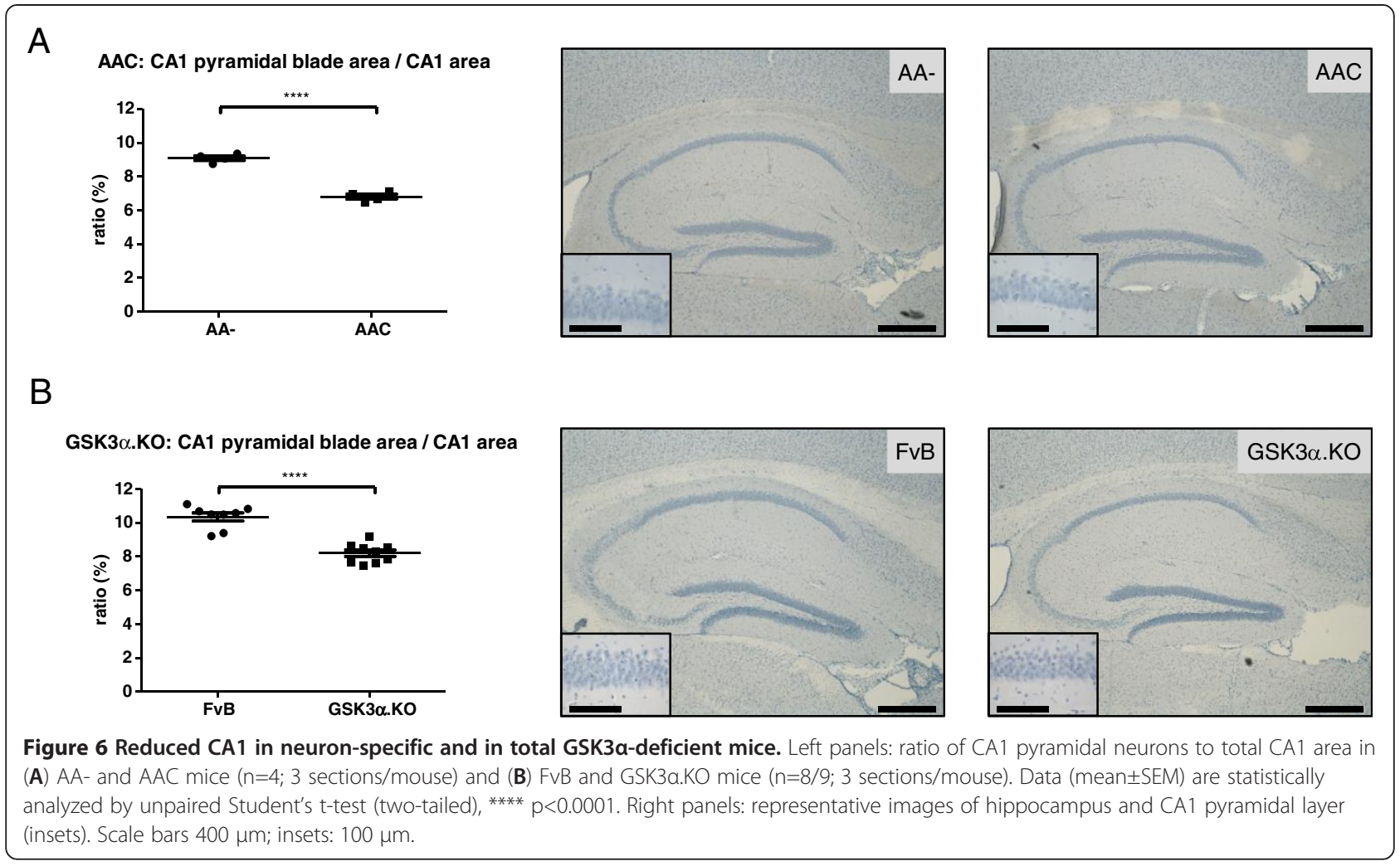

mice ( $<<0.0001$; Figure 7A) pointing to important alterations in basal synaptic transmission imposed by the missing GSK3 $\alpha$ activity. Conversely, paired pulse facilitation (PPF) was similar in sections from AAC and AAmice (Figure 7B) while synaptic fatigue was significantly reduced in AAC mice $(\mathrm{p}<0.0001$; Figure $7 C)$. The data implied that GSK3 $\alpha$ controlled important pre-synaptic physiological mechanisms, and that these functions were not compensated for, nor taken over by GSK3 $\beta$.

Late-LTP (L-LTP), recorded up to 4.5 hours poststimulus, was significantly reduced in AAC mice relative to AA- mice (during the last 2 hours $\mathrm{p}=0.0369$; Figure 7D). The finding argued for a post-synaptic defect caused by the absence of GSK3 $\alpha$, and implied a physiological function for GSK3 $\alpha$ in post-synaptic signal handling, in addition to the accepted contribution of GSK3 $\beta[5,7,14,16,38]$.

The combined electrophysiological data demonstrated, somewhat unexpectedly, that synaptic transmission was importantly deregulated by pre- and post-synaptic actions in mice with neuron-specific deficiency of GSK3 $\alpha$. These findings instigated us to characterize in more detail the motor capacity, the general behavior and the cognition of the neuron-specific GSK3 $\alpha$-deficient mice.

\section{Motor activity and behavior}

AAC mice were subjected to classical motor tests but no important motor-related impairments were noted (Table 1).
Moreover, the AAC mice never showed clasping of the legs, not even at advanced age (18 months), which combined with the motor tests demonstrated that GSK3 $\alpha$ did not contribute appreciably to motor-neuron activity.

AAC mice displayed unaltered anxiety-related behavior, assessed in the classical open-field test (OFT). Both AAC and AA- mice spent similar fractions of the allotted test-time in the corners, the center and the periphery of the arena (Table 1). Moreover, the distance travelled by mice from either genotype was very similar, and so was their overall total activity in the open-field, again underwriting the conclusion that GSK3 $\alpha$ deficiency did not cause motor problems in the AAC mice (Table 1).

The conclusion that neuronal deficit of GSK3 $\alpha$ affected neither motor activity nor anxiety related behavior, was further confirmed in the dark-light paradigm. This well-known task was developed to estimate anxiety, and has been used to measure the effect of anxiolytic and anxiogenic drugs [39,40]. Neither the latency to enter the lighted compartment, nor the time spent there, nor the number of transitions between dark and lighted compartments differed markedly between the AAC and AA- mice (Table 1).

Depressive or depression-like behavior was assessed by the Porsolt forced-swim task, a robust well-established paradigm in rodents [41,42]. Mice were forced to swim in a small water-tank from which they could not escape, 


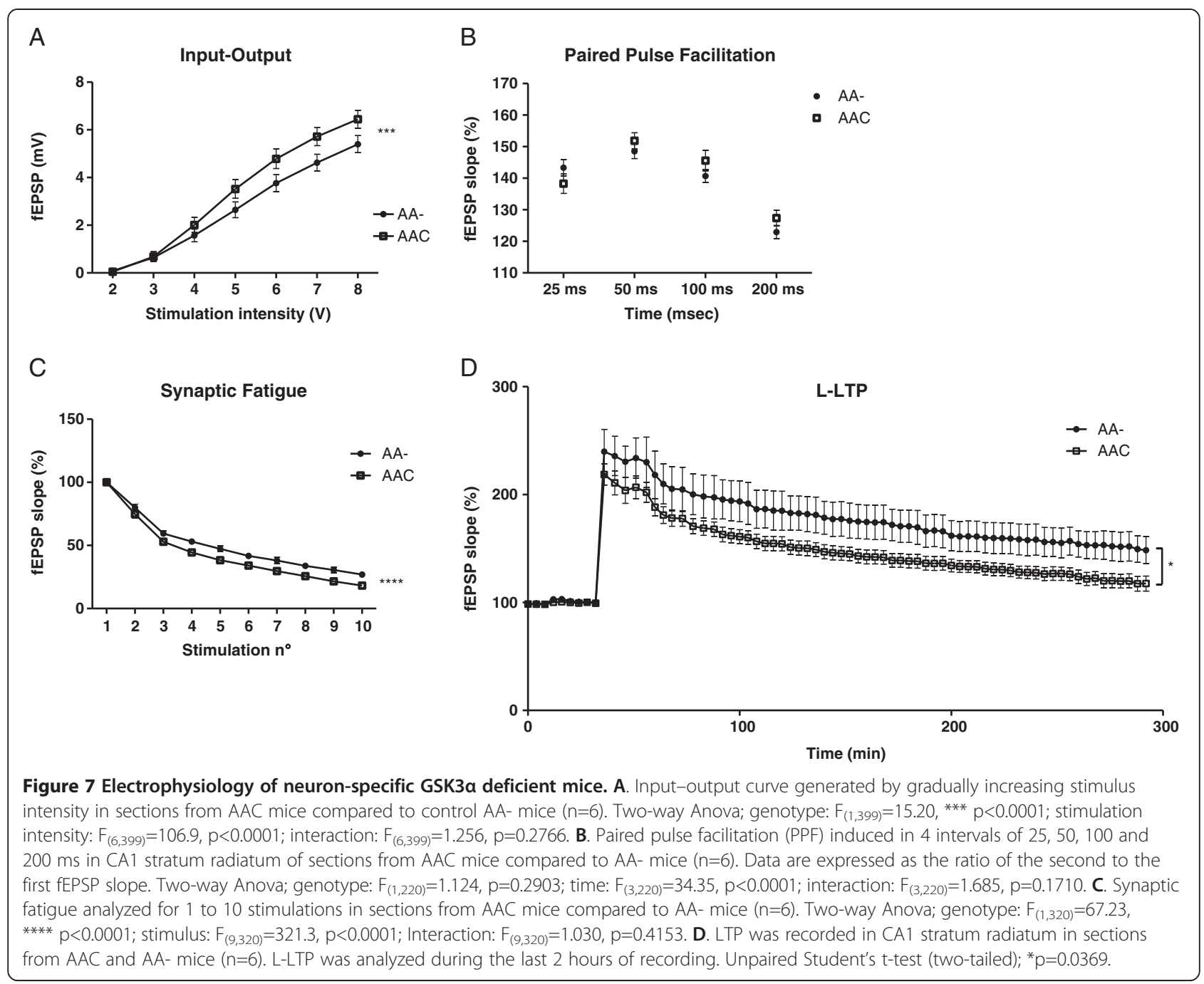

and after an initial bout of forced swimming the mice assumed an immobile floating position. The relative time of passive floating (immobility) was taken as measure of behavioral despair, observed to be decreased by anti-depressants [41]. The test did, however, not discriminate AAC and AA- mice (Table 1), indicating that $\mathrm{AAC}$ mice were not depressed or in a depression-like condition.

The combined data demonstrated that neuronal GSK3 $\alpha$ deficiency did not appreciably impinge on motor activity or on general behavior, nor induced anxiety in the AAC mice.

\section{Cognition: Y-maze \& NORT}

The morphological and electrophysiological defects of the hippocampal region, described above, led us to analyze whether GSK3 $\alpha$ was involved in cognitive processes, besides GSK3 $\beta$. We assessed the cognitive performance of the $\mathrm{AAC}$ mice relative to control
AA- mice in the Y-maze to measure their working memory $[43,44]$, and in the novel object recognition task to assess hippocampus-dependent learning and memory $[31,45,46]$.

In the Y-maze, AAC mice did not show differences in either the number of entries or alternations and displayed only a trend towards a decrease in spontaneous alternations (Table 1).

In the novel object recognition task (NORT), imposed 4 hours following suitable training, the AAC mice exhibited a significant decreased recognition index compared to AA- mice ( $\mathrm{p}=0.0176$; Table 1$)$, without a difference in distance traveled or mobility (Table 1). The test was repeated and the outcome confirmed in three different cohorts of age- and gender-matched AAC and AAmice. The compelling evidence for a distinct memory impairment of the AAC mice, thereby established a function of GSK $3 \alpha$ in synaptic plasticity, underpinning our electrophysiological data. 
Table 1 Motor ability, cognition and pain sensitivity of AA- and AAC mice (age 3-4 mo)

\begin{tabular}{|c|c|c|c|c|}
\hline Task & Parameter (units) & AA- & AAC & $\mathrm{p}$ \\
\hline \multicolumn{5}{|c|}{ Motor } \\
\hline Inverted grid & Time (sec) & $60.00 \pm 0.00$ & $58.40 \pm 1.60$ & N/A \\
\hline Beamwalk & Time (sec) & $180.00 \pm 0.00$ & $171.80 \pm 8.25$ & $\mathrm{~N} / \mathrm{A}$ \\
\hline \multicolumn{5}{|c|}{ Behavior \& cognition } \\
\hline \multirow[t]{3}{*}{ Y-maze } & Index & $75.06 \pm 2.59$ & $69.42 \pm 2.69$ & 0.1475 \\
\hline & Entries (n) & $27.91 \pm 2.55$ & $26.75 \pm 1.54$ & 0.6956 \\
\hline & Alterations (n) & $19.55 \pm 2.11$ & $17.08 \pm 1.12$ & 0.3031 \\
\hline \multirow[t]{5}{*}{ OFT } & Corners (sec) & $338.60 \pm 24.53$ & $312.30 \pm 23.31$ & 0.4469 \\
\hline & Periphery (sec) & $556.70 \pm 8.67$ & $561.70 \pm 5.89$ & 0.6331 \\
\hline & Center (sec) & $43.36 \pm 8.67$ & $38.36 \pm 5.89$ & 0.6331 \\
\hline & Distance moved $(\mathrm{cm})$ & $3972 \pm 444.4$ & $4327 \pm 397.0$ & 0.5573 \\
\hline & Mobility (\%) & $66.77 \pm 4.02$ & $68.75 \pm 4.23$ & 0.7385 \\
\hline \multirow[t]{3}{*}{ Dark/Light } & Latency (sec) & $52.27 \pm 24.46$ & $55.17 \pm 24.84$ & 0.9348 \\
\hline & Transitions (n) & $4.18 \pm 0.74$ & $4.33 \pm 0.75$ & 0.8872 \\
\hline & Time spent in light (sec) & $106.60 \pm 28.04$ & $89.00 \pm 15.24$ & 0.5776 \\
\hline Porsolt swim test & Immobility (\%) & $53.96 \pm 4.78$ & $49.55 \pm 3.70$ & 0.4673 \\
\hline \multirow[t]{3}{*}{${ }^{*}$ NORT } & Index & $59.56 \pm 3.78$ & $45.82 \pm 3.76$ & 0.0176 \\
\hline & Distance moved $(\mathrm{cm})$ & $2158 \pm 293.4$ & $2040 \pm 273.4$ & 0.7712 \\
\hline & Mobility (\%) & $37.05 \pm 4.04$ & $33.78 \pm 3.96$ & 0.5708 \\
\hline PIA & Latency to dark (sec) & $180.50 \pm 36.35$ & $248.60 \pm 25.77$ & 0.1334 \\
\hline \multicolumn{5}{|c|}{ Pain sensitivity } \\
\hline \multirow[t]{3}{*}{ Footshock threshold } & Flinching (mA) & $0.1350 \pm 0.0183$ & $0.1792 \pm 0.0208$ & 0.1347 \\
\hline & Jumping (mA) & $0.4833 \pm 0.0546$ & $0.6042 \pm 0.0711$ & 0.2189 \\
\hline & Vocalizations (mA) & $0.3300 \pm 0.0300$ & $0.3875 \pm 0.0418$ & 0.2948 \\
\hline * Hot plate task & Time (sec) & $8.90 \pm 0.74$ & $6.92 \pm 0.43$ & 0.0256 \\
\hline * Capsaicin sensitivity & Wipes (n) & $60.33 \pm 5.82$ & $82.91 \pm 5.75$ & 0.0136 \\
\hline
\end{tabular}

Abbreviations: OFT, open-field test; NORT, novel object recognition task; PIA, passive inhibitory avoidance; *, denote statistically significant differences.

\section{Cognition: PIA}

We compared AAC \& AA- mice in the cognitive task of passive inhibitory avoidance (PIA), presented here separately for several reasons. On the one hand, PIA surprisingly revealed a trend, not for defective but for improved cognition of the AAC mice (Table 1). On the other hand, PIA revealed a markedly increased sensitivity of the AAC mice to the electric footshocks they received during their conditioning for the PIA task. These unexpected observations led us to analyze the pain-sensitivity of the AAC mice.

The reaction to an electric foot-shock was in itself not exacerbated by the neuron-specific GSK3 $\alpha$ deficiency: the AAC mice showed similar intensity thresholds as the control AA- mice for jumping, vocalization and flinching in response to foot-shocks (Table 1). In contrast, thermal nociception measured by the hotplate test $\left(55^{\circ} \mathrm{C}\right)$ revealed a significantly lower latency for paw-withdrawal in the AAC mice ( $\mathrm{p}=0.0256$; Table 1$)$.
We analyzed the potential implication of the capsaicin receptor TRPV1 in these sensory reactions, by the capsaicin eye sensitivity test [47]. The number of wiping actions with the forelimbs following administration of a diluted capsaicin solution to the eyes, was significantly higher in the AAC mice than in the AA- mice ( $\mathrm{p}=0.0136$; Table 1$)$. The TRPV1 channel, well-known to control nociception was therefore analyzed in trigeminal ganglia and dorsal root ganglia from AAC and AA- mice by q-RT-PCR. No differences in TRPV1 mRNA levels were observed, while also brain TRPV1 protein levels, analyzed by western blotting were not affected in the AAC mice. We consequently excluded a TRPV1-mediated mechanism in the augmented pain sensitivity invoked by neuron-specific GSK3 $\alpha$ deficiency.

\section{Biochemical modification of GSK3 isozymes by cognitive training of wild-type mice}

Biochemical analysis of the brain of AAC mice surprisingly demonstrated that performing the PIA task itself 
led to biochemical modifications of the GSK3 isozymes. To define whether cognitive training was directly responsible, we biochemically analyzed hippocampal protein extracts from wild-type mice following cognitive training in PIA and NORT for total GSK3 $\alpha / \beta$ levels, and for phosphorylated pS21/S9 and pY279/Y216 isoforms.

Total GSK $3 \alpha / \beta$ protein levels were not affected by the PIA task, but the inhibitory phosphorylation at S21/S9 in $\mathrm{GSK} 3 \alpha / \beta$ were significantly increased (Figure 8A). The same trend of inhibitory serine phosphorylation of both GSK3 kinases was observed in wild-type mice subjected to NORT (Figure 9A). Concomitant with these indications for decreased kinase activity of both GSK3 isozymes, a moderate increase in phosphorylation of Y279/Y216 in GSK3 $\alpha / \beta$ was evident when brain was analyzed $30 \mathrm{~min}$ after the PIA-test.

Surprisingly, the foregoing biochemical observations extended to protein Tau in the same brain extracts: total levels of endogenous mouse Tau were increased in the hippocampus of wild-type mice subjected to the PIA and NORT tasks (Figure 8B; Figure 9B). The possible mechanisms underlying these observations, and their eventual relation, remain unknown and deserve to be explored, because they comply with recent observations that lower tau levels profoundly affect physiological and pathological neurological characteristics [48-52].

\section{Comparative analysis of GSK3a.KO mice and GSK3a. KOxTau.P301L bigenic mice}

While GSK3 $\beta$ proved to be a very effective Tau-kinase in mouse brain, with important functional consequences [26-29,36], GSK3 $\alpha$ remained largely overlooked in this respect. Here we investigated the contribution of GSK3 $\alpha$ to the phosphorylation of protein Tau in the GSK $3 \alpha$. KOxTau.P301L bigenic mice that we derived specifically for this goal. The alternative, i.e. to generate AACxTau. P301L bigenic mice, would have required a much more complex genetic assembly, because 5 alleles would have been needed: (i) homozygosity of the floxed GSK3 $\alpha$ alleles, (ii) homozygosity of the transgenic Tau.P301L alleles, (iii) at least one allele of the Thy1 Cre-recombinase transgene. To save valuable time and effort we decided to restrict our investigation to the GSK3 $\alpha . K O x T a u . P 301 L$ bigenic mice, which were more straightforward to breed, and yielded the same information.

\section{Motor behavior}

We compared GSK3 $\alpha . K O$ and bigenic GSK3 $\alpha$.KOxTau. P301L mice by most of the behavioral and cognitive tests also performed with the AAC mice, described in foregoing sections. Both genotypes were compared to their appropriate age- and gender-matched controls, c.q. GSK3 $\alpha . K O$ to wild-type FvB mice and GSK3 $\alpha . K O x T a u$. P301L to the parental Tau.P301L mice.
The GSK3 $\alpha . K O$ mice did not show clasping of the legs, nor any impairment on the rotarod (Table 2), which extended our observations on the AAC mice and strengthening the conclusion that GSK3 $\alpha$ did not importantly affect motor ability.

It was therefore surprising to note that the bigenic GSK3 $\alpha . K O x T a u . P 301 L$ mice performed significantly worse than Tau.P301L mice on the rotarod task, already at young age (1-2 months) $(\mathrm{p}=0.0268$; Table 2$)$. We consistently observed and reported that the parental Tau. P301L mice became motor impaired only at adult age (6-8 months). These defects correlated with the progressive phosphorylation of protein Tau.P301L, and were attributed to the sensitivity of motor neurons to beginning tauopathy $[29,35,36]$. Obviously, the responsible mechanisms must be more complex because the lack of GSK3 $\alpha$ was not expected to increase, but rather to decrease the phosphorylation of protein Tau, as experimentally observed (cfr next section).

\section{Behavior and cognition}

In the open-field test, young GSK3 $\alpha$.KO mice tended to spend more time in the corners and less in the center of the arena compared to matched wild-type mice $(\mathrm{p}=0.0070$ and $\mathrm{p}=0.0677$ respectively; Table 2$)$. The distance moved, as well as the speed and total activity were all lowered by GSK3 $\alpha$ deficiency. Because motor problems were not indicated by the clasping and rotarod tests, we concluded stress-induced anxiety to be responsible, possibly reflecting a depression-like state or even mania, as proposed for GSK3 overexpressing mice [53,54]. Very similar behavior of bigenic GSK3 $\alpha$.KOxTau.P301L mice was observed, including significantly decreased travel and mobility in the open field $(\mathrm{p}<0.0001$ and $\mathrm{p}=0.0007$ respectively; Table 2) demonstrating that no additional problems were conferred in the bigenic combination on either of the parental phenotypes.

The cognitive performance, measured in the Y-maze task, revealed similar highly significant defects in GSK3 $\alpha . K O$ and GSK3 $\alpha$.KOxTau.P301L mice in the number of entries and in alternations $(\mathrm{p}=0.0003$ and $\mathrm{p}=0.0007$ respectively; Table 2 ), although the index did not differ between either type of GSK3 $\alpha$-deficient mice and their respective controls. In NORT, the GSK3 $\alpha . K O$ and GSK3 $\alpha . K O x T a u . P 301 L$ mice presented both with a minor cognitive impairment, and their decreased general activity and locomotion confirmed the open-field observations (Table 2).

In the dark-light paradigm, the GSK3 $\alpha . K O$ mice tended towards increased latency to enter the lighted compartment (Table 2) but with a highly significant decrease in the number of transitions $(\mathrm{p}=0.0059$; Table 2). The GSK3 $\alpha . K O x T a u . P 301 L$ mice were similarly impaired as the GSK3 $\alpha . K O$ mice in the number of transitions 
A

PIA: GSK3 $\alpha$ total

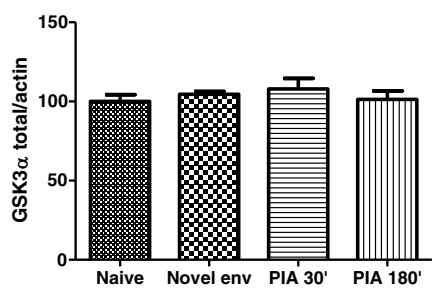

PIA: GSK3 $\alpha$ pS21

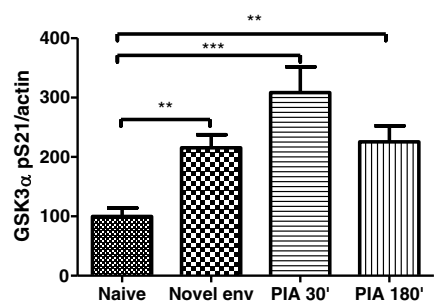

PIA: GSK3 $\alpha$ pS21/total

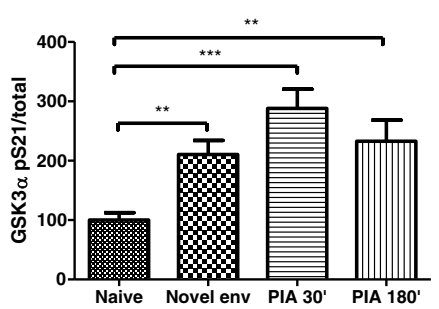

PIA: GSK3 $\alpha$ pY279

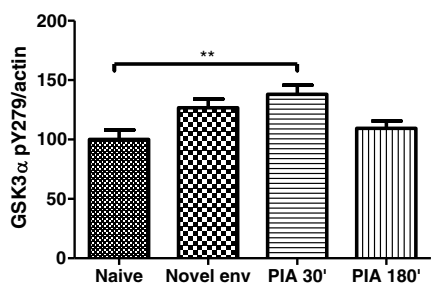

PIA: GSK3 $\alpha$ pY279/total

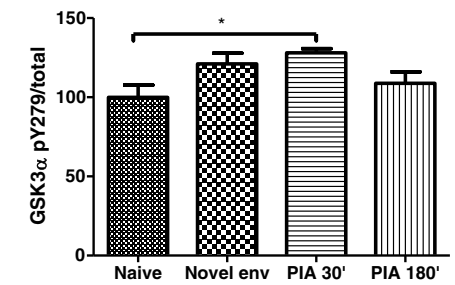

PIA: GSK3 $\beta$ total

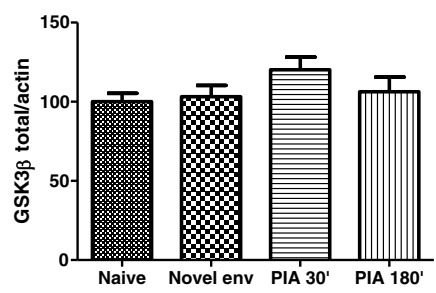

PIA: GSK3 $\beta$ pS9

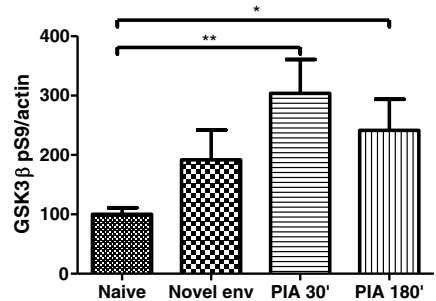

PIA: GSK3 $\beta$ pS9/total

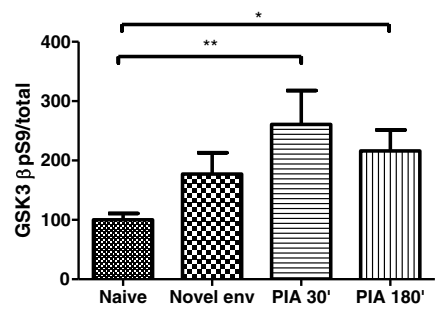

PIA: GSK3 $\beta$ pY216

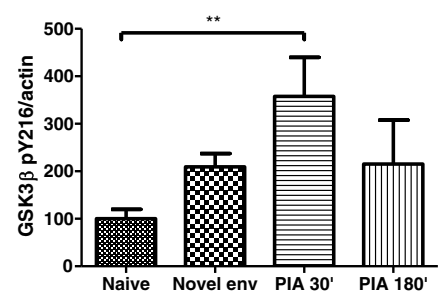

PIA: GSK3 $\beta$ pY216/total

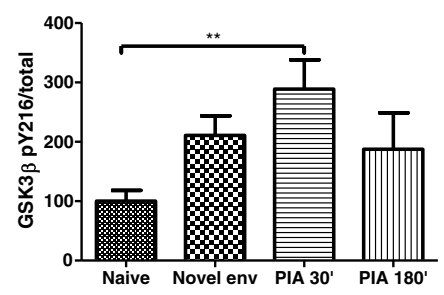

B

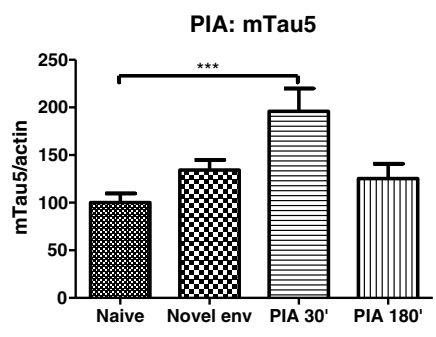

PIA: mAD2
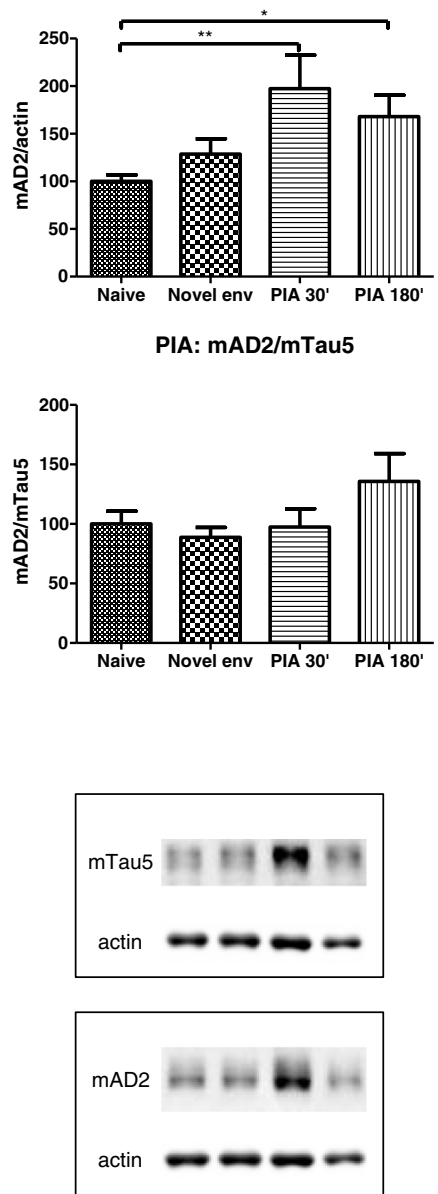

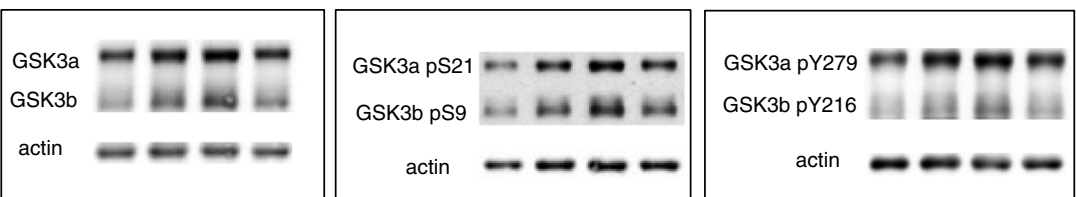

Figure $\mathbf{8}$ (See legend on next page.) 
(See figure on previous page.)

Figure 8 Biochemical repercussions of PIA on GSK3 and protein tau in hippocampus of wild-type mice. A. Biochemical analysis of GSK3 by western blotting of total protein extracts from hippocampus of FvB wild-type mice $(n=10)$ at different timepoints before or after they performed the PIA task ( $n=6$ per timepoint). All data normalized to actin and reported relative to naive control mice. Data (mean \pm SEM) are statistically analyzed by one-way Anova (Dunnet's post hoc test compared to naive). GSK3a: $F_{(3,24)}=0.5422 ; p=0.6581 . G S K 3 \beta$ : $F_{(3,24)}=1.523$; $p=0.2339$. GSK3a pS21: $F_{(3,24)}=12.58 ; p<0.0001$. GSK3a pS21/total: $F_{(3,24)}=12.11 ; p<0.0001$. GSK3 $\beta$ pS9: $F_{(3,24)}=5.240 ; p=0.0063 . \quad G S K 3 \beta$ pS9/total: $F_{(3,24)}$ $=4.832 ; p=0.0090$. GSK3a pY279: $F_{(3,24)}=4.973 ; p=0.0080$. GSK3a $p Y 279 /$ total: $F_{(3,24)}=3.346 ; p=0.0359$. GSK3 $p Y 216: F_{(3,24)}=3.875 ; p=0.0216 . G S K 3 \beta$ pY216/total: $F_{(3,24)}=4.528 ; p=0.0119$. * $p<0.05 ;{ }^{* *} p<0.01 ;{ }^{* *} p<0.001$. Lower panels show representative western blots. B. Biochemical analysis of protein Tau by western blotting of total protein extracts from hippocampus of FvB wild-type mice $(n=10)$ at different timepoints before or after they performed the PIA task ( $n=6$ per timepoint). All data normalized to actin and reported relative to naive control mice. Data (mean \pm SEM) are statistically analyzed by one-way Anova (Dunnet's post hoc test compared to naive). Tau5: $F_{(3,24)}=7.625 ; p=0.0009$. $A D 2: F_{(3,24)}=5.162 ; p=0.0068$. AD2/Tau5: $F_{(3,24)}=1.761 ; p=0.1815$. * $p<0.05 ;{ }^{* *} p<0.01 ;{ }^{* *} p<0.001$. Lower panels show representative western blots.

( $\mathrm{p}<0.0001$; Table 2) but, in addition, spent significant less time in the lighted sector than age-matched young Tau. P301L mice ( $\mathrm{p}=0.0018$; Table 2).

The combined data demonstrated interestingly distinct contributions of GSK $3 \alpha$ to cognition and to anxietyrelated behavior of mice. This was exacerbated by the pathological contribution of the onset of tauopathy, which were nevertheless still minor in the young GSK3 $\alpha$.KOxTau. P301L mice (age 1-2 months). Conversely, both GSK3 $\alpha$. KO and GSK3 $\alpha . K O x T a u . P 301 L$ mice were hypoactive in several tasks, compared to their respective controls, which was not caused by motor deficits.

\section{GSK3a as Tau kinase in brain in vivo}

We first assessed the contribution of GSK $3 \alpha$ to the phosphorylation of endogenous mouse protein Tau (mTau) in AAC and GSK3 $\alpha$.KO mice, compared to AAand wild-type mice, respectively. In second instance, biochemical analysis was extended to human protein Tau. P301L in the bigenic GSK3 $\alpha . K O x T a u . P 301 L$ combination compared to the parental Tau.P301L mice.

\section{Decreased phosphorylation of endogenous mouse Tau in AAC and in GSK3a.KO mice}

We analyzed biochemically total protein extracts of the forebrain of AAC and AA- mice ranging in age from 3 to 18 months. No major differences between AAC and AA- mice were evident in total forebrain endogenous mTau levels, while a progressive increase with age was observed to be similar in both genotypes (Figure 10A).

We went on to analyze three major phosphorylated epitopes of mTau, i.e. pS199, pT231 and pS396/pS404, because these are well-known physiological and pathological markers. They are proposed to depend on GSK3 activity, although to a different extent depending on the test system and model. In hippocampal and forebrain extracts of AAC mice we noted the general trend for decreased phosphorylation of mTau at all three epitopes, indicating a contribution of GSK3 $\alpha$ (Figure 10B). In GSK3 $\alpha . K O$ mice phosphorylation of mTau was decreased in the hippocampus. Especially the level of AD2 was significantly reduced by the absence of GSK $3 \alpha$, although it is generally presented as a GSK3 $\beta$ dependent epitope (Figure 10C). The reduced phosphorylation of mTau was further sustained by the significantly decreased levels of pS199 in the cortex of GSK3 $\alpha$.KO mice (Figure 10C). Obviously, GSK3 $\alpha$ contributed to the physiological phosphorylation of various sites on endogenous protein Tau in mouse brain.

\section{Decreased phosphorylation of human Tau.P301L in brain of GSK3a.KOxTau.P301L mice}

Similar biochemical analysis of human Tau.P301L in the brain of bigenic GSK3 $\alpha . K O x T a u . P 301 L$ mice revealed the generalized trend of decreased phosphorylation at the same epitopes analyzed. The level of pT231 was significantly decreased in hippocampus and in cortex of GSK3 $\alpha . K O x T a u . P 301 L$ mice compared to Tau.P301L mice, while the pS199 levels were significantly decreased in the cortex (Figure 10D).

Although the three phosphorylated epitopes that we analyzed are classically attributed to depend on the activity of the GSK3 $\beta$ isozyme, our current data demonstrated that also the less well studied GSK3 $\alpha$ isozyme contributed to the phosphorylation of protein Tau at these physiologically and pathologically important phospho-epitopes.

\section{Discussion}

To clarify the neurological functions of GSK3 $\alpha$, the isoform that is far less well studied than GSK3 $\beta$, we generated mice that were deficient in GSK $3 \alpha$, specifically in neurons. Available mice with floxed GSK3 $\alpha$ genes [30] were crossed with Thy1-Cre mice, with neuron-specific expression of Cre recombinase, first used for neuronal Presenilin1 gene inactivation [31]. In addition, we took advantage of the fortuitous finding of offspring with total GSK3 $\alpha$ deficiency (GSK3 $\alpha . K O)$. Both strains were expanded, and moreover GSK3 $\alpha . \mathrm{KO}$ mice crossed with Tau.P301L mice, yielding unique models that define GSK3 $\alpha$ as Tau kinase in vivo.

The most marked observations combined from all GSK3 $\alpha$-deficient mice are discussed: (i) striking independent regulation of the GSK3 isozymes; (ii) numerous 

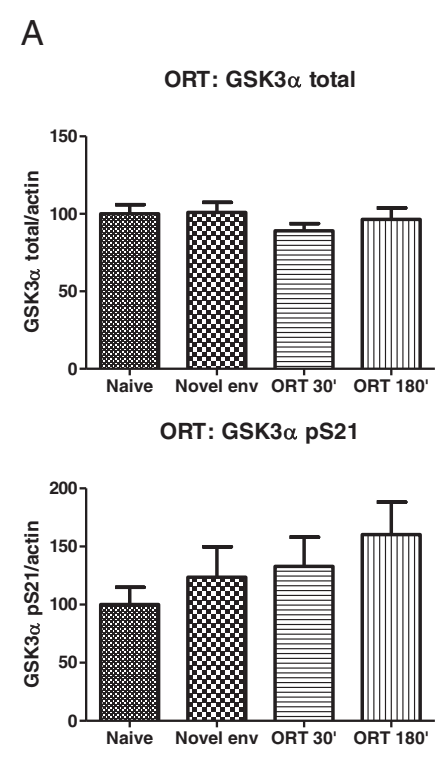

ORT: GSK3 $\alpha$ pS21/total
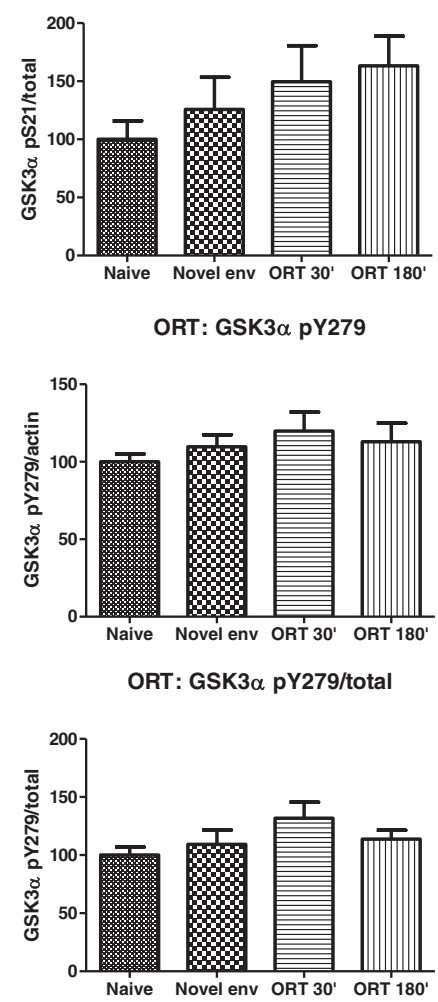
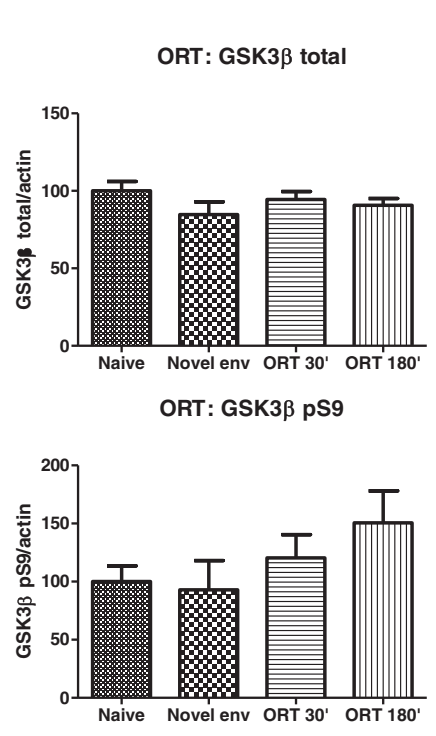

ORT: GSK3 $\beta$ pS9/total
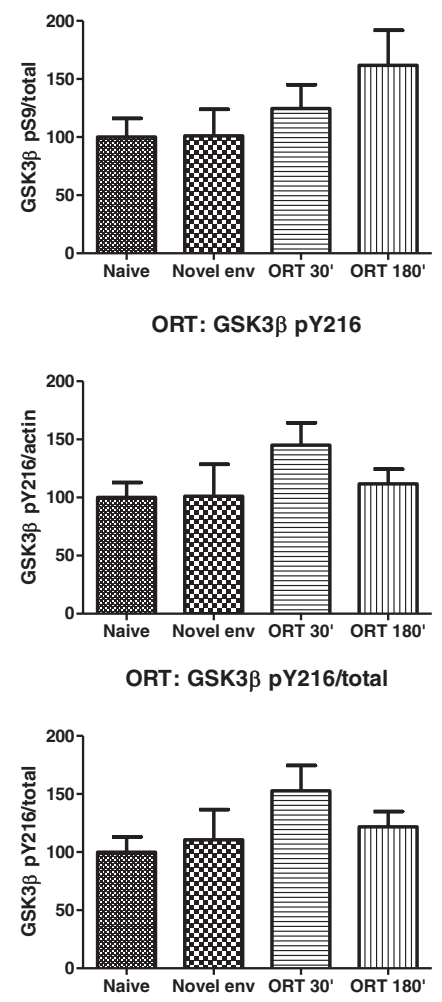

B
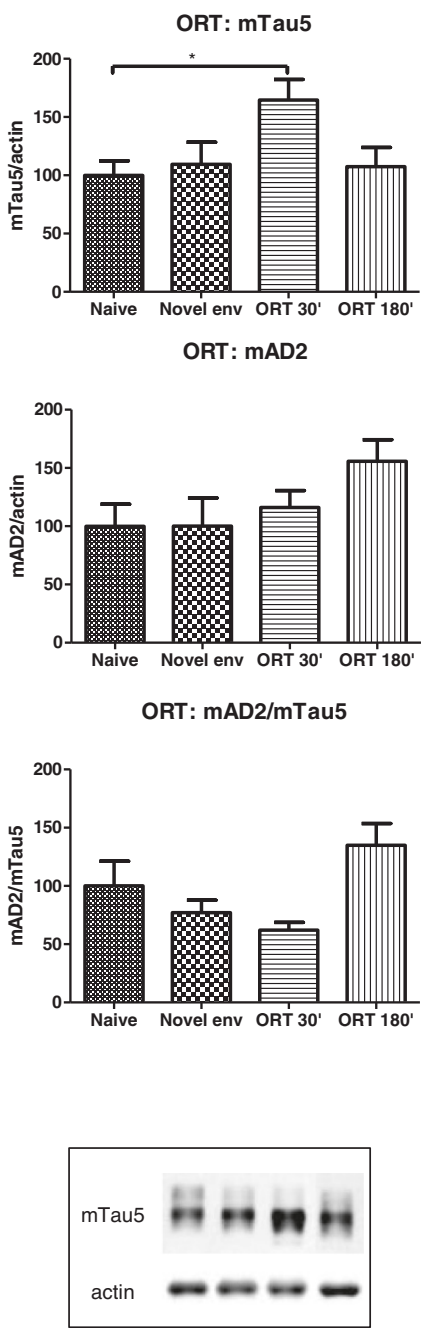

mAD2

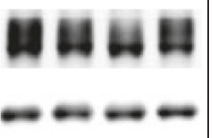

actin
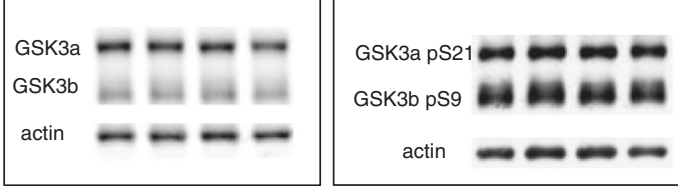

GSK3a pY279

GSK3b pY216 ka ka ba ka

actin

Figure 9 (See legend on next page.) 
(See figure on previous page.)

Figure 9 Biochemical repercussions of NORT on GSK3 and Tau in hippocampus of wild-type mice. A. Biochemical analysis of GSK3 by western blotting of total protein extracts from hippocampus of FvB wild-type mice $(n=10)$ at difference timepoints before or after they performed the NORT task ( $n=6$ per timepoint). All data normalized to actin and reported relative to naive control mice. Data (mean $\pm S E M)$ are statistically analyzed by one-way Anova (Dunnet's post hoc test compared to naive). GSK3a: $F_{(3,24)}=0.6609 ; p=0.5842$. GSK3 $\beta$ : $F_{(3,24)}=1.131 ; p=0.3566$. GSK3a $p S 21: F_{(3,24)}=1.351 ; p=0.2816$. GSK3a pS21/total: $F_{(3,24)}=1.529 ; p=0.2327 . G S K 3 \beta p S 9: F_{(3,24)}=1.469 ; p=0.2479 . G S K 3 \beta p S 9 /$ total: $F_{(3,24)}=1.699 ;$ $p=0.1939$. GSK3a $p Y 279: F_{(3,24)}=1.002 ; p=0.4091$. GSK3a pY279/total: $F_{(3,24)}=1.871 ; p=0.1614$. $G S K 3 \beta p Y 216: F_{(3,24)}=1.302 ; p=0.2967$. $G S K 3 \beta p Y 216 /$ total: $F_{(3,24)}=1.580 ; p=0.2203$. Lower panels show representative western blots. B. Biochemical analysis of protein Tau by western blotting of total protein extracts from hippocampus of FvB wild-type mice $(n=10)$ at difference timepoints before or after they performed the NORT task ( $n=6$ per timepoint). All data normalized to actin and reported relative to naive control mice. Data (mean \pm SEM) are statistically analyzed by one-way Anova (Dunnet's post hoc test compared to naive). Tau5: $F_{(3,24)}=3.286 ; p=0.0380$. $A D 2: F_{(3,24)}=1.637 ; p=0.2071$. $A D 2 /$ Tau5: $F_{(3,24)}=2.593 ; p=0.0761$.

* $p<0.05$. Lower panels show representative western blots.

neuroanatomical, behavioral and cognitive traits depending on GSK3 $\alpha$; (iii) physiological and pathological phosphorylation of protein Tau.

We finally discuss the regulation of GSK3 activity by phosphorylation during behavioral tasks.

\section{GSK3 isozymes act independently}

Biochemical data, presented here and before [23] demonstrate conclusively that tampering with one of the GSK3 isozymes do not noticeably affect the other. Both GSK3 isozymes, despite their close structural and functional relations, are controlled independently of each other. Physiologically, they share substrates, but have preferred sets of substrates in brain [55]. Translational implications are not evident, i.e. specific inhibitors of either isozyme would not per se be better for treating neurological diseases.

\section{GSK3a contributes to neuroanatomy, behavior and cognition}

In sharp contrast to GSK3 $\beta$, complete deficiency of GSK3 $\alpha$ during mouse embryogenesis allows normal development even including CNS. The marked exception of male spermatogenesis, cannot be discussed here in detail for lack of analytical data, but GSK3 $\alpha$ appears more essential than GSK3 $\beta$ for normal development and functioning of sperm-flagellae.

We concentrated specifically on CNS but observed normal brain anatomy in mice with total or with neuron-specific deficiency of GSK3 $\alpha$. The interesting

Table 2 Motor ability and cognition of young female GSK3a.KO and GSK3a.KOxTau.P301L mice

\begin{tabular}{|c|c|c|c|c|c|c|c|}
\hline Task & Parameter & FvB & GSK3a.KO & $\mathbf{p}$ & Tau.P301L & GSK3a.KO x Tau.P301L & $\mathrm{p}$ \\
\hline \multicolumn{8}{|c|}{ Motor } \\
\hline * Rotarod & Time (sec) & $299.4 \pm 0.6$ & $300.0 \pm 0.0$ & NA & $293.3 \pm 5.5$ & $254.6 \pm 17.4$ & 0.0268 \\
\hline \multicolumn{8}{|c|}{ Behavior \& cognition } \\
\hline * Y-maze & Index & $66.95 \pm 1.66$ & $71.15 \pm 4.84$ & 0.3553 & $69.91 \pm 3.46$ & $62.80 \pm 5.28$ & 0.2600 \\
\hline * & Entries (n) & $42.22 \pm 2.84$ & $23.17 \pm 2.06$ & 0.0003 & $45.10 \pm 1.49$ & $27.38 \pm 3.18$ & $<0.0001$ \\
\hline * & Alterations (n) & $26.89 \pm 1.88$ & $15.00 \pm 1.67$ & 0.0007 & $30.10 \pm 1.74$ & $16.13 \pm 2.16$ & 0.0001 \\
\hline \multirow[t]{3}{*}{ * OFT } & Corners (sec) & $292.7 \pm 11.6$ & $380.0 \pm 28.9$ & 0.0070 & $282.3 \pm 11.10$ & $337.8 \pm 29.6$ & 0.0745 \\
\hline & Periphery (sec) & $549.9 \pm 8.08$ & $572.8 \pm 7.08$ & 0.0677 & $539.0 \pm 6.55$ & $554.8 \pm 11.09$ & 0.2169 \\
\hline & Center (sec) & $50.15 \pm 8.08$ & $27.19 \pm 7.08$ & 0.0677 & $61.02 \pm 6.55$ & $45.22 \pm 11.09$ & 0.2169 \\
\hline * & Distance $(\mathrm{cm})$ & $5972 \pm 303.7$ & $3315 \pm 389.6$ & 0.0001 & $6500 \pm 341.3$ & $3178 \pm 442.2$ & $<0.0001$ \\
\hline * & Mobility (\%) & $74.12 \pm 1.41$ & $53.00 \pm 4.59$ & 0.0002 & $77.72 \pm 1.09$ & $55.08 \pm 5.95$ & 0.0007 \\
\hline * NORT & Index & $77.21 \pm 4.61$ & $69.71 \pm 1.25$ & 0.2189 & $78.46 \pm 1.90$ & $59.91 \pm 7.14$ & 0.0075 \\
\hline * & Distance $(\mathrm{cm})$ & $4017 \pm 263.5$ & $2319 \pm 329.9$ & 0.0014 & $4459 \pm 303.6$ & $1924 \pm 411.6$ & 0.0002 \\
\hline * & Mobility (\%) & $66.78 \pm 1.96$ & $44.86 \pm 5.09$ & 0.0005 & $71.49 \pm 2.03$ & $41.91 \pm 7.88$ & 0.0005 \\
\hline * Dark/Light & Latency (sec) & $21.67 \pm 4.90$ & $27.33 \pm 3.99$ & 0.4242 & $19.20 \pm 4.25$ & $11.88 \pm 2.97$ & 0.1985 \\
\hline * & Transitions (n) & $11.11 \pm 1.01$ & $6.17 \pm 1.05$ & 0.0059 & $11.00 \pm 0.54$ & $4.625 \pm 0.80$ & $<0.0001$ \\
\hline * & Time in light (sec) & $150.40 \pm 4.49$ & $132.5 \pm 29.08$ & 0.4669 & $139.30 \pm 6.51$ & $74.88 \pm 17.52$ & 0.0018 \\
\hline
\end{tabular}

Abbreviations: OFT, open-field test; NORT, novel object recognition task; PIA, passive inhibitory avoidance; * denote statistically significant differences. 
A
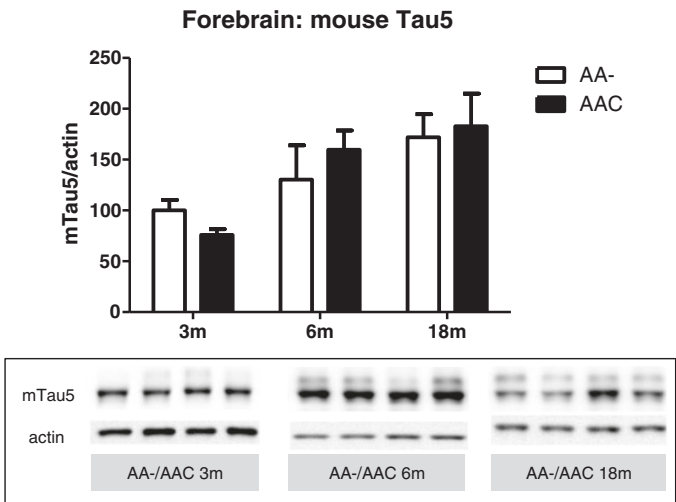

B

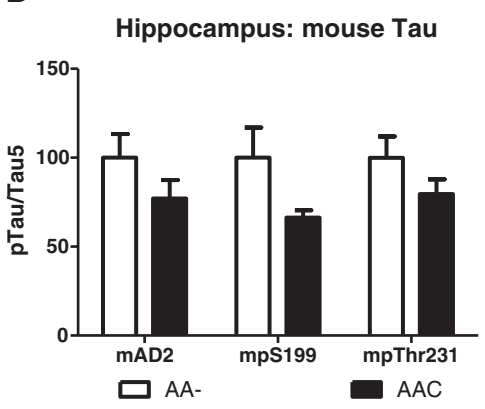

C

Hippocampus: mouse Tau
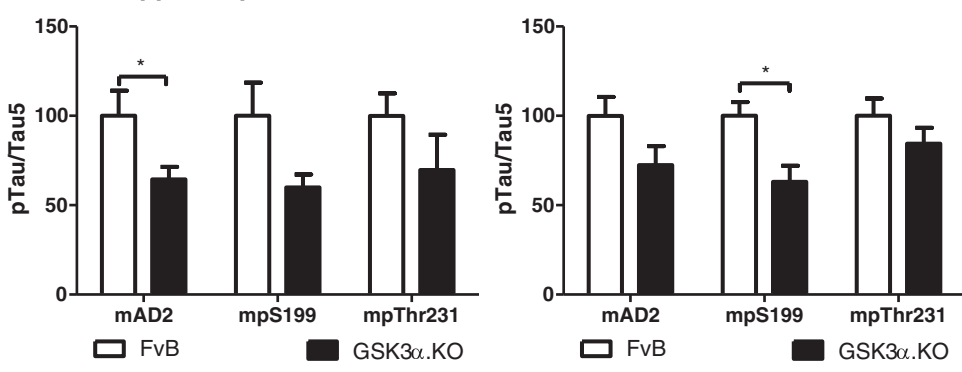

D
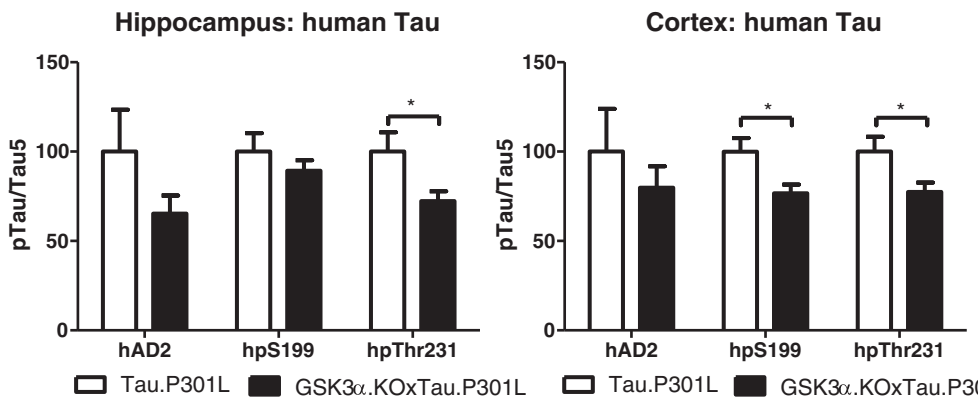
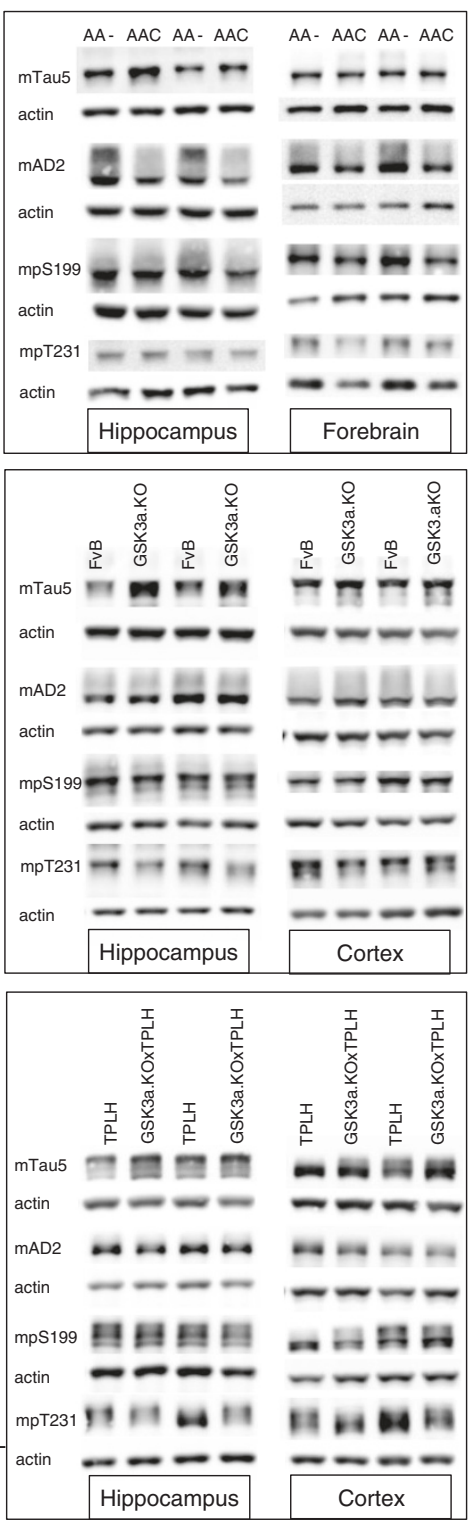

Figure 10 (See legend on next page.) 
(See figure on previous page.)

Figure 10 Biochemical analysis of protein Tau in GSK3a deficient mice. A. Biochemical analysis by western blotting of total protein extracts from forebrain of $A A C$ and $A A$ - mice aged 3, 6 and 18 months ( $n=5 /$ age). Tau protein levels are normalized to actin and expressed relative to

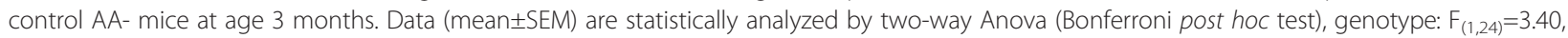
$p=0.5093$; age: $F_{(2,24)}=37.60, p=0.0027$; interaction: $F_{(2,24)}=0.20, p=0.7759$. Lower panels show representative western blots. B. Biochemical analysis by western blotting for phospho-epitopes pS396/404, pS199 and pT231 of endogenous mouse Tau in total protein extracts from hippocampus and forebrain of AAC and control AA- mice. C. Biochemical analysis by western blotting for phospho-epitopes pS396/404, pS199 and pT231 of endogenous mouse Tau in total protein extracts from hippocampus and cortex of GSK3a.KO and FVB wild-type mice. D. Biochemical analysis by western blotting for phospho-epitopes pS396/404, pS199 and pT231 of human Tau.P301L in total protein extracts from hippocampus and cortex of GSK3a.KOxTau.P301L mice and the parental Tau.P301L mice. In panels B-D, all data are normalized for total Tau and reported relative to the respective control mice. Data (mean \pm SEM) are statistically analyzed by unpaired Student's t-test (two-tailed), $n=6$ or 7 per genotype; * $p<0.05$.

exception is the reduction of CA1 pyramidal layers, which matures with the hippocampus mainly postnatally in mice [56]. This coincides with onset of expression of the Cre-recombinase transgene in the AAC mice, driven by the mouse Thy1 gene promoter [31]. The identical CA1 defect in both strains of GSK3 $\alpha$-deficient mice not only confirm and strengthen each other, but imply that GSK3 $\alpha$ did not impact importantly on any other brainregion during embryonal development. The specific neuroanatomical defect in CA1 caused by GSK3 $\alpha$ deficiency thereby exemplify the fact that the GSK3 isozymes do not compensate for each other. A similar CA1 defect was observed in mice with neuron-specific deficiency of GSK3 $\beta$ [23] but only when they grow old ( $\mathrm{H}$. Maurin, B. Lechat, P. Borghgraef, F. Van Leuven; data not shown). Consequently, while GSK $3 \alpha$ contributes to the postnatal development of the CA1 subregion, GSK3 $\beta$ could be more important for the ageing CA1. Conversely, both GSK3 kinases are activated by amyloid by increased tyrosine phosphorylation [29], and both can contribute to neurodegeneration. These important issues must be analyzed further, given the vulnerability of CA1 in AD $[57,58]$.

The combined electrophysiological and cognitive defects of neuron-specific GSK3 $\alpha$ deficient mice imply more important physiological functions of GSK3 $\alpha$ in plasticity, acting both pre- and post-synaptically, than anticipated. The CA1 defective neuroanatomy is complemented by defects in hippocampal LTP and in cognition, which considerably extends observations on defective learning in a similar, independent total GSK $3 \alpha$-deficient mouse strain [21]. Although no motor impairments was observed in our GSK $3 \alpha$ deficient mice, the cross with Tau.P301L mice led to severe motor problems on rotarod, and overall reduced mobility. Because GSK3 $\alpha$ did not negatively affect motor performance, the large data-sets from the various tasks strengthen the observed impairments of memory and learning.

Overall, neuronal GSK3 $\alpha$ contributes more subtly to behavior and cognition, judged from mice with neuronspecific deficiency. In contrast, total lack of GSK3 $\alpha$ caused significantly more defects and impairments in more tasks and for more parameters, with increased anxiety as extra noteworthy.

\section{GSK3a phosphorylates protein Tau in brain in vivo}

We focus on physiopathological roles of both GSK3 kinases in experimental AD-models by investigating contributions to amyloid pathology [23,29] and to the comorbid tauopathy $[29,35,36]$. In our hands, neither GSK3 isozyme appreciably affected the production of amyloid peptides in mouse brain in vivo [23], while we have validated GSK3 $\beta$ as effective Tau-kinase [26,27,29,36]. Data presented here demonstrate physiological and pathological contributions of GSK $3 \alpha$ to the phosphorylation of protein Tau, respectively of endogenous wild-type mouse Tau and of human Tau.P301L. In both instances, GSK3 $\alpha$ acts effectively as Tau-kinase in vivo, although its quantitative contribution appears less than that of GSK3 $\beta$. In translational terms, these data do not warrant the search for specific GSK3 $\beta$ inhibitors that spare GSK3 $\alpha$, as a therapeutic means for tauopathies in which GSK3 are thought to contribute.

\section{GSK3 is phosphorylated by cognitive training}

While phosphorylation of $\mathrm{S} 21 / \mathrm{S} 9$ in $\mathrm{GSK} 3 \alpha / \beta$ respectively, is a negative control, the precise mechanism and effects of tyrosine phosphorylation at Y279/Y216 remain enigmatic. The presumed auto-phosphorylation in either GSK3 isozyme, increases their kinase activity and releases the otherwise stringent requirement for substratepriming by other kinases. These are a prerequisite for effective phosphorylation by GSK3 of specified prolinedependent substrate sites [6]. The combined serine and tyrosine phosphorylation appears contradictory, although S21/S9 phosphorylation is accepted as overriding inhibiting parameter. We conclude that cognitive training in the paradigms described, inhibits the activity of both GSK3 kinases in the brain of wild-type mice by the demonstrated increased phosphorylation of S21/S9 in GSK3 $\alpha / \beta$.

\section{Conclusions}

GSK3 $\alpha$ activity affect not only the phosphorylation of protein Tau, but also impacts widely on motor activity and clinical parameters, although the repercussions are complex and more subtle than anticipated. These conclusions fit the notion that both GSK3 isozymes exert 
kinase activities on many protein substrates of varied identity, surpassing protein Tau as a microtubule binding protein. Structural and motor proteins, e.g. kinesins, tubulins, adapter proteins and others, are regulated by different types of phosphorylation, and several are known or suspected substrates for either or both GSK3 kinases. Our biochemical results on the impact of learning and memory on the phosphorylation of both GSK3 isozymes, and on the levels of protein Tau, need to be examined further in wild-type and informative transgenic mice.

\section{Methods}

\section{Generation of mice with neuronal GSK3a deficiency}

Mice with floxed GSK3 $\alpha$ alleles [30] were crossed with Thy1-Cre recombinase transgenic mice [31]. Offspring was genotyped by PCR and qPCR on genomic DNA isolated from tail biopsies to define wild-type, floxed and recombined GSK3 $\alpha$ alleles (see Results for details). Primers: 5'CCCCCACCAAGTGATTTCACTGCTA3' and 5'AAC ATGAAATTCCGGGCTCCAACTCTAT3'. We generated neuron-specific GSK3 $\alpha$-deficient mice denoted as AAC and mice with floxed GSK3 $\alpha$ genes but lacking Crerecombinase were used as controls (AA-). Mice with total knock-out of GSK3 $\alpha$ (GSK3 $\alpha$.KO) were generated and also analyzed. We further generated GSK3 $\alpha$.KOxTau.P301L bigenic mice to analyze the pathological phosphorylation of Tau.P301L protein by GSK3 $\alpha$.

\section{Biochemical analysis}

Mice of either gender; as specified with the results, were anesthetized (Nembutal; $100 \mathrm{mg} / \mathrm{kg}$, i.p), perfused transcardiacally for $2 \mathrm{~min}$ with ice-cold saline and the brain rapidly removed. Eventually, as indicated with the results, brains were placed on ice-cold glass plates for dissection of hippocampus and forebrain. Tissues were snap-frozen in liquid nitrogen and stored at $-70^{\circ} \mathrm{C}$ until homogenization. Total homogenates were prepared in $25 \mathrm{mM}$ Tris, $150 \mathrm{mM} \mathrm{NaCl}, 1 \times$ complete proteinase cocktail, $1 \mathrm{mM}$ PMSF, $1 \mathrm{mM}$ EGTA, $1 \mathrm{mM}$ EDTA, $30 \mathrm{mM} \mathrm{NaF}, 1 \mathrm{nM}$ okadaic acid, $0.2 \mathrm{mM} \mathrm{Na}_{3} \mathrm{VO}_{4}, 5 \mathrm{mM}$ $\mathrm{Na}_{4} \mathrm{P}_{2} \mathrm{O}_{7}$ (pH 7.6). We used $6 \mathrm{ml}$ buffer (ice-cold) per gram frozen tissue for homogenization with a cooled glass-teflon Potter-Elvejhem type of homogenizer (20 strokes, $700 \mathrm{rpm})$. Total homogenates $(\mathrm{TH})$ were obtained after brief centrifugation $\left(14000 \mathrm{~g}, 10 \mathrm{~min}, 4^{\circ} \mathrm{C}\right)$ to remove debris, and samples were stored in aliquots at $-25^{\circ} \mathrm{C}$ until analysis $[35,59,60]$.

Proteins were denatured, reduced and separated on 10\% Tris-Glycine SDS-PAGE gels (Anamed, Germany). Proteins were transferred to nitrocellulose membranes and, after blocking, probed overnight $\left(4^{\circ} \mathrm{C}\right)$ with primary antibodies: for both GSK3 proteins (Biosource, \#44-610), for GSK3 $\alpha / \beta$ pY279/216 (Biosource, \#44-604) and GSK3 $\alpha / \beta$
pS21/9 (Cell Signalling, \#9331); total tau and phosphorylated tau were detected with Tau5 (Pharmingen, \#556319), AD2 (Biorad, \#56484), pT231 (Invitrogen, \#355200), pS199 (Invitrogen, \#44734G). Membranes were rinsed in TBS-Tween $0.1 \%$ and incubated with appropriate HRPlabeled secondary antibody diluted in 5\% skimmed milk-powder in TBS-Tween 0.1\%). Reactions were developed by chemiluminescence (ECL-prime; GE Healthcare) followed by digital picture acquisition and analysis (LAS 4000; ImageQuant v7.0; GE Healthcare).

\section{Immunohistological analysis}

Anesthetized mice (Nembutal; $100 \mathrm{mg} / \mathrm{kg}$, i.p.) were perfused transcardiacally with ice-cold saline and the brain rapidly removed. One hemisphere was immersion-fixed overnight in $4 \%$ paraformaldehyde in phosphate-buffered saline (PBS) at $4^{\circ} \mathrm{C}$, rinsed, and stored at $4^{\circ} \mathrm{C}$ in $\mathrm{PBS}$ containing $0.1 \%$ sodium azide. Sagittal free-floating vibratome sections $(40 \mu \mathrm{m})$ were cut and kept in 24 well plates, in PBS containing $0.1 \%$ azide at $4{ }^{\circ} \mathrm{C}$.

Immunohistochemistry was performed as previously described [29,35,60,61]. After rinsing in PBS, sections were pretreated for 15 min with $1.5 \% \mathrm{H}_{2} \mathrm{O}_{2}$ in $50 \%$ methanol/PBS to eliminate endogenous brain peroxidase activity. Subsequent blocking of nonspecific binding sites by incubation in $10 \%$ fetal calf serum, $0.1 \%$ Triton X-100 in PBS (blocking solution), was followed by incubation at $4^{\circ} \mathrm{C}$ overnight with rabbit polyclonal GSK3 primary antibodies: GSK3 $\alpha$ (Cell Signaling, \#9338) and GSK3 $\beta$ (Cell Signaling, \#9315). After rinsing (0.1\% Triton X-100 in PBS), sections were incubated for $1 \mathrm{~h}$ with the biotinylated goat anti-rabbit secondary antibody, diluted 1:500 in blocking buffer. Sections were further incubated for 30 min with avidin-biotin complex (Vectastain ABC Elite, Vector labs). Sections were rinsed in PBS and incubated for $5 \mathrm{~min}$ in $50 \mathrm{mM}$ Tris- $\mathrm{HCl}$ (pH7.6), before staining with $3,3^{\prime}$-diaminobenzidine $(0.5 \mathrm{mg} / \mathrm{ml}), 0.3 \%$ $\mathrm{H}_{2} \mathrm{O}_{2}$ in $50 \mathrm{mM}$ Tris- $\mathrm{HCl}(\mathrm{pH}$ 7.6). Mayer's hematoxylin (Sigma, \#51275) was used for counterstaining, prior to dehydration by passage through a graded series of ethanolwater mixtures. After two washes in 100\% xylol, the dehydrated sections were mounted using (DePeX) [60].

\section{Hematoxylin staining}

Free-floating sections were incubated overnight at $4^{\circ} \mathrm{C}$ in PBS-TX100 (0.1\%), washed 3 times in PBS before being mounted on silanized glass-slides. The sections were allowed to dry for 2 hours at $50^{\circ} \mathrm{C}$ before staining with Mayer's Hematoxylin (Sigma, \#51275) followed by dehydration in the classical graded ethanol/water series. After two washes in $100 \%$ xylol, the sections were mounted (DePeX). The area of the CA1 pyramidal layer was measured on 3 sections per mouse, spaced $120 \mu \mathrm{m}$ apart, by 
digital image analysis and expressed relative to the entire CA1 area, measured on the same sections.

\section{Breeding performance and sperm analysis}

Breeding performance for all genotypes was estimated from the number of litters and pups produced in our breeding colony. Sperm analysis was essentially as described [62]: cauda epididymis was dissected and minced in $500 \mu \mathrm{L}$ of in-vitro fertilization IVF medium (Minimum Essential Medium supplemented with $0.025 \mathrm{mg} / \mathrm{ml}$ sodium pyruvate, $0.07 \mathrm{mg} / \mathrm{ml}$ penicillin, $0.05 \mathrm{mg} / \mathrm{ml}$ streptomycin, $3.8 \mu \mathrm{g} / \mathrm{ml}$ EDTA and $3 \mathrm{mg} / \mathrm{ml} \mathrm{BSA}$ ) and kept at $37^{\circ} \mathrm{C}$ for $10 \mathrm{~min}$. The cell suspension was analyzed by the swim-up test: $100 \mu \mathrm{L}$ was diluted with $500 \mu \mathrm{L}$ warm medium and incubated at $37^{\circ} \mathrm{C}$ for $15 \mathrm{~min}$. The upper and lower fractions were separated and cells counted in Neubauer chambers. Relative sperm motility was calculated as the ratio of spermatozoids in the upper and lower fractions.

\section{Behavior}

Behavioral experiments were designed to allow performance in consecutive tasks without interference, with stressful tasks, e.g. footshock threshold, assessed in distinct groups of mice. We always analyzed age- and gender-matched AA- and AAC mice ( $n=11$ or 12; except for beamwalk and grid hanging tests with $n=5$ ). Behavioral tasks were assessed in FvB females $(n=9)$, Tau. P301L females $(n=10)$, GSK3 $\alpha$. KO females $(n=6)$ and GSK3 $\alpha . K O x T a u . P 301 L$ females $(n=8)$. Experiments were performed over a total time-span of 8 weeks to minimize interference between tasks.

\section{Rotarod}

Motor ability and coordination was assessed by the classical rotarod [35]. Mice were trained for 3 days in 3 sessions per day $(3 \times 3 \mathrm{~min}$ at $20 \mathrm{rpm})$. Test-trials were performed on day 4 , during $5 \mathrm{~min}$ with the rod rotating at increasing speed ( 4 to $40 \mathrm{rpm}$ ). Data are expressed as the time the mice remained on the rod.

\section{Inverted grid test}

Performed with a grid $(425 \times 266 \mathrm{~mm}, 1291$ Eurostandard type III H, Tecniplast) kept at $40 \mathrm{~cm}$ above the bench that was covered with soft tissues. Data are expressed as the time in seconds, until the mice released their grip after inversion of the grid (maximum $60 \mathrm{sec}$ ) [26].

\section{Beam-walk}

The test was performed by placing the mouse in the middle of a horizontal rod (diameter $1 \mathrm{~cm}$, length $1 \mathrm{~m}$ ) placed $35 \mathrm{~cm}$ above the bench that was covered with soft tissues. Data are expressed as the time spent on the rod (maximum 3 minutes) [35].

\section{Open field test}

Mice were placed in a corner of a perspex box $(52 \times 52 \times 40 \mathrm{~cm})$ with black walls and translucent floor, dimly illuminated from underneath. The activity of individual mice over a 10 min observation period was recorded and analyzed by a dedicated system (EthoVisionXT 7.0 Noldus, Wageningen, The Netherlands). Calculated parameters included total distance, speed, time spent in defined sections [29].

\section{Y-maze}

Mice were placed in one arm of the Y-shaped maze constructed from opaque plastic, and allowed to explore the 3 arms for $6 \mathrm{~min}$. The number of entries in each arm, and the alterations were recorded. Entry was considered effective when all 4 limbs were located inside the arm [44].

\section{Dark/light test}

This task was performed in the same perspex box as open field test, now divided in two compartments: one remaining open and illuminated from above, and one darkened by covering with a fitting box made of grey opaque plastic. Mice were initially placed in the dark compartment and observed for $5 \mathrm{~min}$ by recording the time spent in each compartment and the number of transitions between dark/light compartments [29].

\section{Passive inhibitory avoidance task (PIA)}

This task was performed in a two-chambered inner box comprising lit and dark sections separated by a trapdoor, all placed inside a larger sound-tight box. For training, mice were initially placed in the lit section and after $10 \mathrm{sec}$ the trap-door was opened to allow the mouse to enter the dark section, with an electric footshock $(0.5 \mathrm{~mA} ; 2 \mathrm{sec})$ delivered after $2 \mathrm{sec}$. The mice were kept for $15 \mathrm{sec}$ in the dark compartment before being returned to the home cage. Retention was assessed 24 hours later, by placing the mouse in the lit section again and measuring its latency, i.e. the time that elapsed before entry into the dark compartment [29].

\section{Novel object recognition task (NORT)}

NORT was performed as described [31]. Briefly, mice were habituated for $10 \mathrm{~min}$ to the perspex open-field box, dimly illuminated from below. On day 2 the mice were observed in the same box for $8 \mathrm{~min}$ in the presence of object A (acquisition). The time that the mouse explored object A was recorded, with the criterion that the snout was within $1 \mathrm{~cm}$ of the object. The $8 \mathrm{~min}$ retention trial was performed 4 hours later, by placing the mouse in the box with the additional novel object B. The time that the animal spent exploring both objects 
was recorded as $t A$ and $t B$, respectively, and the retention index $(\mathrm{RI})$ was defined as $\mathrm{tB} /(\mathrm{tA}+\mathrm{tB}) \times 100$.

\section{Porsolt forced swim task}

The original test [42] was adapted by placing the mice in a large glass beaker of 1 liter (diameter $10 \mathrm{~cm}$ ) filled with $800 \mathrm{ml}$ water $\left(23^{\circ} \mathrm{C}\right)$ that was changed after each individual test. Mice were allowed to habituate for $2 \mathrm{~min}$ followed by 4 min observation with recording the time of immobility and passive floating.

\section{Footshock sensitivity}

Mice were placed in the perspex box used for PIA with metal wire floor and allowed for 2 min to habituate before receiving an electric foot-shock $(0.1 \mathrm{~mA}, 1 \mathrm{sec})$. Subsequently, the mice received every $30 \mathrm{sec}$ an electric foot-shock with an increment of $0.05 \mathrm{~mA}$ until $0.6 \mathrm{~mA}$ and of $0.1 \mathrm{~mA}$ until a maximum of $1 \mathrm{~mA}$. The voltage at which the mice reacted by flinching, jumping or vocalizing was recorded [63].

\section{Electrophysiology}

Electrophysiological analysis was performed as described [14]. Acute hippocampal sections $(400 \mu \mathrm{m})$ were kept in artificial cerebrospinal fluid (ACSF) $124 \mathrm{mM} \mathrm{NaCl}$, $5 \mathrm{mM} \mathrm{KCl}, 26 \mathrm{mM} \mathrm{NaHCO} 3,1.24 \mathrm{mM} \mathrm{NaH} 2 \mathrm{PO} 4$, $2.5 \mathrm{mM} \mathrm{CaCl} 2,1.3 \mathrm{mM} \mathrm{MgSO} 4,10 \mathrm{mM}$ glucose aerated with $95 \% \mathrm{O} 2 / 5 \% \mathrm{CO} 2$. Sections were placed on the interface recording chamber and kept at $28^{\circ} \mathrm{C}$ for $90 \mathrm{~min}$ under perfusion with ACSF $(1 \mathrm{ml} / \mathrm{min})$. Bipolar twisted nickel-chrome electrodes were used to stimulate Schaffer's collaterals, while extracellular field excitatory postsynaptic potentials (fEPSP) were recorded in the CA1 stratum radiatum using low resistance glass electrodes filled with ACSF. LTP was induced by strong stimulation, 4 trains at $100 \mathrm{~Hz}$ of $1 \mathrm{~s}$ with 5 min intervals, with subsequent measurement of the potentiated response. The slope of fEPSP was averaged over 4 consecutive responses and normalized to the mean value of baseline recorded for $30 \mathrm{~min}$ prior to stimulus. For each slice the input-output curve was established by increasing stimulus intensity and synaptic fatigue was measured by recording the output during high frequency stimulation. Paired-pulse facilitation was determined at four different inter-pulse intervals: $50 \mathrm{~ms}, 100 \mathrm{~ms}, 150 \mathrm{~ms}$ and $200 \mathrm{~ms}$, and measured by the relative ratio of the second to the first fEPSP slope.

\section{Statistical analysis}

All data are expressed as mean \pm SEM. The statistical tests were performed with dedicated software (Graphpad Prism 5.04). Behavioral data (Tables 1 and 2) were analyzed by Student's t-Test (unpaired, two-tailed). Other datasets were analyzed by one - or two-way Anova with appropriate post-hoc test, as specified in the legends. Classical levels of statistical significance are indicated with the data.

\section{Animal healthcare}

All experiments were performed in accordance with regional, national and European regulations concerning animal welfare and animal experimentation, and were authorized and supervised by the University animal welfare commission (Ethische Commissie Dierenwelzijn, KULeuven).

All animal experiments were performed by certified researchers conforming to regional, national and European regulations concerning animal welfare and animal experimentation, authorized and supervised by the university animal welfare commission (Ethische Commissie Dierenwelzijn, KULeuven). We formally declare that we comply to the European FP7-Decision 1982/2006/EC, Article 611, i.e. all research activities is carried out in compliance with fundamental ethical principles and all experiments are approved and overlooked by the Animal Welfare Commission.

\begin{abstract}
Abbreviations
ACSF: Artificial cerebrospinal fluid; AD: Alzheimer's disease; CA1: Cornus ammonis 1; fEPSP: Field excitatory postsynaptic potential; GSK3: Glycogen synthase kinase 3; LTP: Long term potentiation; NORT: Novel object recognition task; OFT: Open field test; PIA: Passive inhibitory avoidance; PPF: Paired pulse facilitation; TH: Total homogenate; TRPV1: Transient receptor potential cation channel subfamily $\vee$ member 1 .
\end{abstract}

\section{Competing interests}

The authors declare no financial competing interests.

\section{Authors' contributions}

FVL originated the concept and overall design of the study. IDW and LR performed the electrophysiological analysis. BL, HM and JVL monitored breeding, performed genotyping and analyzed behavior. PB and HM performed immunohistochemistry and analyzed data. BL and HM performed biochemical analysis and sperm analysis. BL, HD, HM and TJ performed general characterization of mice. $\mathrm{HM}, \mathrm{BL}$, IDW and $\mathrm{FVL}$ wrote the manuscript. All authors approved the final manuscript.

\section{Acknowledgements}

We thank many collaborators and fellow scientists for technical assistance, advice, scientific and moral support, and we thank especially Jim R. Woodgett for the floxed mice. We thank Gabriela Casteels for expert administrative assistance. The investigations were supported by Fonds Wetenschappelijk Onderzoek-Vlaanderen (FWO-Vlaanderen); Instituut Wetenschap \& Techniek (IWT); EEC 7th Framework Program (neuro.GSK3); de Rooms-fund; KULeuven-Research Fund; KULeuven-Research \& Development. HM acknowledges Marie Curie fellowship MEST CT 2005/020013 NEURAD.

\section{Author details}

${ }^{1}$ Experimental Genetics Group - LEGTEGG, Department Human Genetics, KULeuven, B-3000, Leuven, Belgium. ²Department Neurosciences, University Mons-Hainaut, B-7000, Mons, Belgium. ${ }^{3}$ Present address: Nencki Institute Experimental Biology, 3 Pasteur Street, 02-093, Warsaw, Poland.

Received: 2 April 2013 Accepted: 22 May 2013

Published: 25 May 2013 


\section{References}

1. Patel S, Doble B, Woodgett JR: Glycogen synthase kinase-3 in insulin and Wnt signalling: a double-edged sword? Biochem Soc Trans 2004, 32:803-808.

2. Doble BW, Woodgett JR: GSK-3: tricks of the trade for a multi-tasking kinase. J Cell Sci 2003, 116:1175-1186.

3. Jope RS, Johnson GW: The glamour and gloom of glycogen synthase kinase-3. Trends Biochem Sci 2004, 29:95-102.

4. Hanger DP, Noble W: Functional implications of glycogen synthase kinase-3-mediated tau phosphorylation. Int J Alzheimer's Disease 2011, 2011:352805.

5. Kremer A, Louis JV, Jaworski T, Van Leuven F: GSK3 and Alzheimer's disease: facts and fiction.... Front Mol Neurosci 2011, 4:1-10.

6. Cole A, Frame S, Cohen P: Further evidence that the tyrosine phosphorylation of glycogen synthase kinase-3 (GSK3) in mammalian cells is an autophosphorylation event. Biochem J 2004, 377:249-255.

7. Hooper C, Killick R, Lovestone S: The GSK3 hypothesis of Alzheimer's disease. J Neurochem 2008, 104:1433-1439.

8. Ishiguro K, Shiratsuchi A, Sato S, Omori A, Arioka M, Kobayashi S, Uchida T, Imahori K: Glycogen synthase kinase $3 \beta$ is identical to tau protein kinase I generating several epitopes of paired helical filaments. FEBS Lett 1993, 325:167-172.

9. Bain J, Plater L, Elliott M, Shpiro N, Hastie CJ, McLauchlan H, Klevernic I, Arthur JSC, Alessi DR, Cohen P: The selectivity of protein kinase inhibitors: a further update. Biochem J 2007, 408:297-315.

10. Klein PS, Melton DA: A molecular mechanism for the effect of lithium on development. Proc Natl Acad Sci U S A 1996, 93:8455-8459.

11. Perez-Costas E, Gandy JC, Melendez-Ferro M, Roberts RC, Bijur GN: Light and electron microscopy study of glycogen synthase kinase- $3 \beta$ in the mouse brain. PloS One 2010, 5:e8911.

12. Peineau S, Taghibiglou C, Bradley C, Wong TP, Liu L, Lu J, Lo E, Wu D, Saule E, Bouschet T, Matthews P, Isaac JTR, Bortolotto ZA, Wang YT, Collingridge GL: LTP inhibits LTD in the hippocampus via regulation of GSK3 $\beta$. Neuron 2007, 53:703-717.

13. Hooper C, Markevich V, Plattner F, Killick R, Schofield E, Engel T, Hernandez F, Anderton B, Rosenblum K, Bliss T, Cooke SF, Avila J, Lucas JJ, Giese KP Stephenson J, Lovestone S: Glycogen synthase kinase-3 inhibition is integral to long-term potentiation. Eur J Neurosci 2007, 25:81-86.

14. Dewachter I, Ris L, Jaworski T, Seymour CM, Kremer A, Borghgraef $P$, De Vijver H, Godaux E, Van Leuven F: GSK3 $\beta$, a centre-staged kinase in neuropsychiatric disorders, modulates long term memory by inhibitory phosphorylation at serine-9. Neurobiol Dis 2009, 35:193-200.

15. Kim W-Y, Wang X, Wu Y, Doble BW, Patel S, Woodgett JR, Snider WD: GSK-3 is a master regulator of neural progenitor homeostasis. Nat Neurosci 2009, 12:1390-1397.

16. Bradley CA, Peineau S, Taghibiglou C, Nicolas CS, Whitcomb DJ, Bortolotto ZA, Kaang B-K, Cho K, Wang YT, Collingridge GL: A pivotal role of GSK-3 in synaptic plasticity. Front Mol Neurosci 2012, 5:1-11.

17. Takashima A: GSK-3ß and memory formation. Front Mol Neurosci 2012, $5: 47-52$.

18. Clayton EL, Sue N, Smillie K, O'Leary T, Bache N, Cheung G, Cole AR, Wyllie DJ, Sutherland C, Robinson PJ, Cousin MA: Dynamin I phosphorylation by GSK3 controls activity-dependent bulk endocytosis of synaptic vesicles. Nat Neurosci 2010, 13:845-851.

19. Smillie KJ, Cousin MA: The role of GSK3 in presynaptic function. Int $J$ Alzheimer's Disease 2011, 2011:263673.

20. Hoeflich KP, Luo J, Rubie EA, Tsao M, Jin O, Woodgett JR: Requirement for glycogen synthase kinase-3 $\beta$ in cell survival and NF-kB activation. Nature 2000, 406:2-6.

21. Kaidanovich-Beilin O, Lipina TV, Takao K, Van Eede M, Hattori S, Laliberté C, Khan M, Okamoto K, Chambers JW, Fletcher PJ, MacAulay K, Doble BW, Henkelman M, Miyakawa T, Roder J, Woodgett JR: Abnormalities in brain structure and behavior in GSK-3alpha mutant mice. Mol Brain 2009, 2:35.

22. Phiel CJ, Wilson CA, Lee VM, Klein PS: GSK-3a regulates production of Alzheimer's disease amyloid- $\beta$ peptides. Nature 2003, 17:435-439.

23. Jaworski T, Dewachter I, Lechat B, Gees M, Kremer A, Demedts D, Borghgraef $\mathrm{P}$, Devijver $\mathrm{H}$, Kügler S, Patel S, Woodgett JR, Van Leuven F: GSK-3a/ $\beta$ kinases and amyloid production in vivo. Nature 2011, 480:E4-E5.

24. Hurtado DE, Molina-Porcel L, Carroll JC, MacDonald C, Aboagye AK, Trojanowski JQ, Lee VM-Y: Selectively Silencing GSK-3 Isoforms Reduces
Plaques and Tangles in Mouse Models of Alzheimer's Disease. J Neurosci 2012, 32:7392-7402.

25. Ly PTT, Wu Y, Zou H, Wang R, Zhou W, Kinoshita A, Zhang M, Yang Y, Cai F, Woodgett J, Song W: Inhibition of GSK3 $\beta$-mediated BACE1 expression reduces Alzheimer-associated phenotypes. J Clin Invest 2013, 123:224-235.

26. Spittaels K, Van den Haute C, Van Dorpe J, Bruynseels K, Vandezande K, Laenen I, Geerts H, Mercken M, Sciot R, Van Lommel A, Loos R, Van Leuven F: Prominent axonopathy in the brain and spinal cord of transgenic mice overexpressing four-repeat human tau protein. Am J Pathol 1999, 155:2153-2165.

27. Spittaels K, Van den Haute C, Van Dorpe J, Geerts H, Mercken M, Bruynseels K, Lasrado R, Vandezande K, Laenen I, Boon T, Van Lint J, Vandenheede J, Moechars D, Loos R, Van Leuven F: Glycogen synthase kinase-3 $\beta$ phosphorylates protein tau and rescues the axonopathy in the central nervous system of human four-repeat tau transgenic mice. J Biol Chem 2000, 275:41340-41349.

28. Engel T, Lucas JJ, Gómez-Ramos P, Moran MA, Avila J, Hernández F: Cooexpression of FTDP-17 tau and GSK-3 $\beta$ in transgenic mice induce tau polymerization and neurodegeneration. Neurobiol Aging 2006, 27:1258-1268

29. Terwel D, Muyllaert D, Dewachter I, Borghgraef $P$, Croes S, Devijver H, Van Leuven F: Amyloid activates GSK-3 $\beta$ to aggravate neuronal tauopathy in bigenic mice. Am J Pathol 2008, 172:786-798.

30. MacAulay K, Doble BW, Patel S, Hansotia T, Sinclair EM, Drucker DJ, Nagy A,

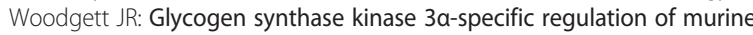
hepatic glycogen metabolism. Cell Metab 2007, 6:329-337.

31. Dewachter I, Reversé D, Caluwaerts N, Ris L, Kuipéri C, Van den Haute C, Spittaels K, Umans L, Serneels L, Thiry E, Moechars D, Mercken M, Godaux E, Van Leuven F: Neuronal deficiency of presenilin 1 inhibits amyloid plaque formation and corrects hippocampal long-term potentiation but not a cognitive defect of amyloid precursor protein [V717l] transgenic mice. J Neurosci 2002, 22:3445-3453.

32. Braak $\mathrm{E}$, Braak $\mathrm{H}$ : Alzheimer's disease: transiently developing dendritic changes in pyramidal cells of sector CA1 of the Ammon's horn. Acta Neuropathol 1997, 93:323-325.

33. Clavaguera F, Bolmont T, Crowther RA, Abramowski D, Frank S, Probst A, Fraser G, Stalder AK, Beibel M, Staufenbiel M, Jucker M, Goedert M, Tolnay $\mathrm{M}$ : Transmission and spreading of tauopathy in transgenic mouse brain. Nat Cell Biol 2009, 11:909-913.

34. Lace G, Savva GM, Forster G, De Silva R, Brayne C, Matthews FE, Barclay JJ, Dakin L, Ince PG, Wharton SB: Hippocampal tau pathology is related to neuroanatomical connections: an ageing population-based study. Brain 2009, 132:1324-1334.

35. Terwel D, Lasrado R, Snauwaert J, Vandeweert E, Van Haesendonck C, Borghgraef P, Van Leuven F: Changed conformation of mutant Tau-P301L underlies the moribund tauopathy, absent in progressive, nonlethal axonopathy of Tau-4R/2N transgenic mice. J Biol Chem 2005, 280:3963-3973.

36. Dutschmann M, Menuet C, Stettner GM, Gestreau C, Borghgraef P, Devijver H, Gielis L, Hilaire G, Van Leuven F: Upper airway dysfunction of TauP301L mice correlates with tauopathy in midbrain and ponto-medullary brainstem nuclei. J Neurosci 2010, 30:1810-1821.

37. Menuet C, Kourdougli N, Hilaire G, Voituron N: Differences in serotoninergic metabolism possibly contribute to differences in breathing phenotype of FVB/N and C57BL/6J mice. J Appl Physiol 2011, 110:1572-1581.

38. Kaidanovich-Beilin O, Beaulieu J-M, Jope RS, Woodgett JR: Neurological functions of the masterswitch protein kinase - GSK-3. Front Mol Neurosci 2012, 5:48-49

39. Imaizumi M, Suzuki T, Machida H, Onodera K: A fully automated apparatus for a light/dark test measuring anxiolytic or anxiogenic effects of drugs in mice. Japanese J. Psychopharmacology 1994, 14:83-91.

40. Marks DR, Tucker K, Cavallin MA, Mast TG, Fadool DA: Awake intranasal insulin delivery modifies protein complexes and alters memory, anxiety, and olfactory behaviors. J Neurosci 2009, 29:6734-6751.

41. David DJP, Renard CE, Jolliet P, Hascoët M, Bourin M: Antidepressant-like effects in various mice strains in the forced swimming test. Psychopharmacology 2003, 166:373-382.

42. Porsolt R, Le Pichon M, Jalfre M: Depression: a new animal model sensitive to antidepressant treatments. Nature 1977, 266:730-732. 
43. Swonger AK, Rech $\mathrm{RH}$ : Serotonergic and cholinergic involvement in habituation of activity and spontaneous alternation of rats in a $\mathrm{Y}$ maze. J Comp Physiol Psychol 1972, 81:509-522.

44. Kim JK, Bae H, Kim M-J, Choi SJ, Cho HY, Hwang H-J, Kim YJ, Lim ST, Kim EK, Kim HK, Kim BY, Shin D-H: Inhibitory effect of poncirus trifoliate on acetylcholinesterase and attenuating activity against trimethyltininduced learning and memory impairment. Biosci Biotechnol Biochem 2009, 73:1105-1112.

45. Rampon C, Tang YP, Goodhouse J, Shimizu E, Kyin M, Tsien JZ: Enrichment induces structural changes and recovery from nonspatial memory deficits in CA1 NMDAR1-knockout mice. Nat Neurosci 2000, 3:238-244.

46. Tang YP, Shimizu E, Dube GR, Rampon C, Kerchner GA, Zhuo M, Liu G, Tsien JZ: Genetic enhancement of learning and memory in mice. Nature 1999, 401:63-69.

47. Neubert JK, King C, Malphurs W, Wong F, Weaver JP, Jenkins AC, Rossi HL, Caudle RM: Characterization of mouse orofacial pain and the effects of lesioning TRPV1-expressing neurons on operant behavior. Mol Pain 2008, 4:43.

48. Dawson HN, Cantillana V, Jansen M, Wang H, Vitek MP, Wilcock DM, Lynch JR, Laskowitz DT: Loss of tau elicits axonal degeneration in a mouse model of Alzheimer's disease. Neuroscience 2010, 169:516-531.

49. Ando K, Leroy K, Héraud C, Yilmaz Z, Authelet M, Suain V, De Decker R, Brion J-P: Accelerated human mutant tau aggregation by knocking out murine tau in a transgenic mouse model. Am J Pathol 2011, 178:803-816.

50. Morris M, Maeda S, Vossel K, Mucke L: The many faces of tau. Neuron 2011, 70:410-426

51. Ke YD, Suchowerska AK, Van der Hoven J, De Silva DM, Wu CW, Van Eersel J, Ittner A, Ittner LM: Lessons from tau-deficient mice. Int J Alzheimer's Disease 2012, 2012:873270.

52. Holth JK, Bomben VC, Reed JG, Inoue T, Younkin L, Younkin SG, Pautler RG, Botas J, Noebels JL: Tau loss attenuates neuronal network hyperexcitability in mouse and Drosophila genetic models of epilepsy. J Neurosci 2013, 33:1651-1659.

53. Christmas J, Maxwell DR: A comparison of the effects of some and other drugs on agressive and exploratory behaviour in mice and rats. Neuropharmacology 1970, 9:17-29.

54. Prickaerts J, Moechars D, Cryns K, Lenaerts I, Van Craenendonck H, Goris I, Daneels G, Bouwknecht JA, Steckler T: Transgenic mice overexpressing glycogen synthase kinase $3 \beta$ : a putative model of hyperactivity and mania. J Neurosci 2006, 26:9022-9029.

55. Soutar MPM, Kim W-Y, Williamson R, Peggie M, Hastie CJ, McLauchlan H, Snider WD, Gordon-Weeks PR, Sutherland C: Evidence that glycogen synthase kinase-3 isoforms have distinct substrate preference in the brain. J Neurochem 2010, 115:974-983.

56. Pérez Delgado MM, Serrano Aguilar PG, Castañeyra Perdomo A, Ferres Torres R: Postnatal development of the Ammon's horn (CA1 and CA3 fields): a karyometric and topographic study. Histol Histopathol 1994, 9:715-721.

57. Mueller SG, Stables L, Du AT, Schuff N, Truran D, Cashdollar N, Weiner MW: Measurement of hippocampal subfields and age-related changes with high resolution MRI at 4T. Neurobiol Aging 2007, 28:719-726.

58. Duyckaerts C, Delatour B, Potier M-C: Classification and basic pathology of Alzheimer disease. Acta Neuropathol 2009, 118:5-36.

59. Muyllaert D, Terwel D, Kremer A, Sennvik K, Borghgraef P, Devijver H, Dewachter I, Van Leuven F: Neurodegeneration and neuroinflammation in cdk5/p25-inducible mice: a model for hippocampal sclerosis and neocortical degeneration. Am J Pathol 2008, 172:470-485.

60. Kremer A, Maurin H, Demedts D, Devijver H, Borghgraef $P$, Van Leuven F: Early improved and late defective cognition is reflected by dendritic spines in Tau.P301L mice. J Neurosci 2011, 31:18036-18047.

61. Jaworski T, Dewachter I, Lechat B, Croes S, Termont A, Demedts D, Borghgraef P, Devijver H, Filipkowski RK, Kaczmarek L, Kügler S, Van Leuven F: AAV-Tau mediates pyramidal neurodegeneration by cell-cycle re-entry without neurofibrillary tangle formation in wild-type mice. PLOS One 2009, 4:e7280
62. Antonangeli F, Petrungaro S, Coluccia P, Filippini A, Ziparo E, Giampietri C: Testis atrophy and reduced sperm motility in transgenic mice overexpressing c-FLIP(L). Fertil Steril 2010, 93:1407-1414.

63. Lamprianou S, Vacaresse N, Suzuki Y, Meziane H, Buxbaum JD, Schlessinge J, Harroch S: Receptor protein tyrosine phosphatase $\gamma$ is a marker for pyramidal cells and sensory neurons in the nervous system and is not necessary for normal development. Mol Cell Biol 2006, 26:5106-5119.

doi:10.1186/1756-6606-6-27

Cite this article as: Maurin et al:: Neurological characterization of mice deficient in GSK3a highlight pleiotropic physiological functions in cognition and pathological activity as Tau kinase. Molecular Brain 2013 $6: 27$.

\section{Submit your next manuscript to BioMed Central and take full advantage of:}

- Convenient online submission

- Thorough peer review

- No space constraints or color figure charges

- Immediate publication on acceptance

- Inclusion in PubMed, CAS, Scopus and Google Scholar

- Research which is freely available for redistribution 